\title{
Evaluation of the carbon content of aerosols from the burning of biomass in the Brazilian Amazon using thermal, optical and thermal-optical analysis methods
}

\author{
L. L. Soto-García ${ }^{1,2}$, M. O. Andreae ${ }^{3}$, T. W. Andreae ${ }^{3}$, P. Artaxo ${ }^{4}$, W. Maenhaut ${ }^{5}$, T. Kirchstetter ${ }^{6}$, T. Novakov ${ }^{6}$, \\ J. C. Chow ${ }^{7}$, and O. L. Mayol-Bracero ${ }^{1}$ \\ ${ }^{1}$ Institute for Tropical Ecosystem Studies, University of Puerto Rico, San Juan, Puerto Rico \\ ${ }^{2}$ Department of Chemistry, University of Puerto Rico, San Juan, Puerto Rico \\ ${ }^{3}$ Biogeochemistry Department, Max Planck Institute for Chemistry, Mainz, Germany \\ ${ }^{4}$ Institute for Physics, University of São Paulo, São Paulo, Brazil \\ ${ }^{5}$ Institute for Nuclear Sciences, Ghent University, Ghent, Belgium \\ ${ }^{6}$ Lawrence Berkeley National Laboratory, Berkeley, California, USA \\ ${ }^{7}$ Desert Research Institute, Reno, Nevada, USA
}

Received: 9 April 2010 - Published in Atmos. Chem. Phys. Discuss.: 19 May 2010

Revised: 4 April 2011 - Accepted: 14 April 2011 - Published: 12 May 2011

\begin{abstract}
Aerosol samples were collected at a pasture site in the Amazon Basin as part of the project LBASMOCC-2002 (Large-Scale Biosphere-Atmosphere Experiment in Amazonia - Smoke Aerosols, Clouds, Rainfall and Climate: Aerosols from Biomass Burning Perturb Global and Regional Climate). Sampling was conducted during the late dry season, when the aerosol composition was dominated by biomass burning emissions, especially in the submicron fraction. A 13-stage Dekati low-pressure impactor (DLPI) was used to collect particles with nominal aerodynamic diameters $\left(D_{p}\right)$ ranging from 0.03 to $0.10 \mu \mathrm{m}$. Gravimetric analyses of the DLPI substrates and filters were performed to obtain aerosol mass concentrations. The concentrations of total, apparent elemental, and organic carbon (TC, $\mathrm{EC}_{\mathrm{a}}$, and $\mathrm{OC}$ ) were determined using thermal and thermal-optical analysis (TOA) methods. A light transmission method (LTM) was used to determine the concentration of equivalent black carbon $\left(\mathrm{BC}_{\mathrm{e}}\right)$ or the absorbing fraction at $880 \mathrm{~nm}$ for the size-resolved samples.

During the dry period, due to the pervasive presence of fires in the region upwind of the sampling site, concentrations of fine aerosols $\left(D_{p}<2.5 \mu \mathrm{m}\right.$ : average $\left.59.8 \mu \mathrm{g} \mathrm{m}^{-3}\right)$ were higher than coarse aerosols $\left(D_{p}>2.5 \mu \mathrm{m}: 4.1 \mu \mathrm{g} \mathrm{m}^{-3}\right)$. Carbonaceous matter, estimated as the sum of the particulate organic matter (i.e., $\mathrm{OC} \times 1.8$ ) plus $\mathrm{BC}_{\mathrm{e}}$, comprised
\end{abstract}

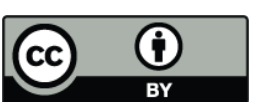

Correspondence to:

O. L. Mayol-Bracero

(omayol@ites.upr.edu) more than $90 \%$ to the total aerosol mass. Concentrations of $\mathrm{EC}_{\mathrm{a}}$ (estimated by thermal analysis with a correction for charring) and $\mathrm{BC}_{\mathrm{e}}$ (estimated by LTM) averaged $5.2 \pm 1.3$ and $3.1 \pm 0.8 \mu \mathrm{g} \mathrm{m}^{-3}$, respectively. The determination of $\mathrm{EC}$ was improved by extracting water-soluble organic material from the samples, which reduced the average light absorption Ångström exponent of particles in the size range of 0.1 to $1.0 \mu \mathrm{m}$ from $>2.0$ to approximately 1.2 . The size-resolved $\mathrm{BC}_{\mathrm{e}}$ measured by the LTM showed a clear maximum between 0.4 and $0.6 \mu \mathrm{m}$ in diameter. The concentrations of OC and $\mathrm{BC}_{\mathrm{e}}$ varied diurnally during the dry period, and this variation is related to diurnal changes in boundary layer thickness and in fire frequency.

\section{Introduction}

Biomass burning in the tropics introduces huge concentrations (up to $40000 \mathrm{~cm}^{-3}$ ) of aerosol particles into the atmosphere (Artaxo et al., 2002). These particles significantly affect climate forcing (Hobbs et al., 1997), cloud properties and precipitation patterns (Rosenfeld, 1999; Koren et al., 2004; Rosenfeld et al., 2008), health (EPA, 2003; Pope and Dockery, 2006), and ecosystems (Barth et al., 2005). The impacts of these particles depend in great part on aerosol composition and size. Therefore, detailed information on their chemical and physical properties is required.

Published by Copernicus Publications on behalf of the European Geosciences Union. 
Particles from biomass burning consist mainly of carbonaceous material (comprising elemental carbon (EC or BC) and organic carbon (OC)), and a small amount of inorganic material (Reid et al., 2005; Andreae and Gelencsér, 2006; Fuzzi et al., 2007). In the Brazilian Amazon, the chemical composition of the inorganic fraction during biomass burning has been extensively studied (Artaxo et al., 1998, 2000, 2002; Andreae et al., 1997; Reid et al., 1998; Formenti et al., 2003; Martin et al., 2010); however, there are relatively few studies focusing on the carbonaceous fraction (Graham et al., 2002; Mayol-Bracero et al., 2002a; Guyon et al., 2003; Falkovich et al., 2005; Decesari et al., 2006; Fuzzi et al., 2007). Findings from the European contribution to the Large-Scale Biosphere-Atmosphere Experiment in Amazonia (LBA-EUSTACH) (Andreae et al., 2002; Graham et al., 2002; Mayol-Bracero et al., 2002a) demonstrated that aerosols were predominantly in the fine fraction (accumulation mode particles) and that most of the carbonaceous material was water-soluble organic carbon (WSOC) (45\%-75\% of the OC). These findings suggested that this aerosol fraction may contribute significantly to the cloud condensation nuclei (CCN) activity (Mayol-Bracero et al., 2002a; Roberts et al., 2002). It was also shown that polycarboxylic acids and probably HULIS (humic-like substances) may be responsible for at least $26 \%$ of the WSOC fraction (Mayol-Bracero et al., 2002a). The polycarboxylic acid water-soluble fraction is effective at lowering the surface tension of cloud droplets, implying that these compounds might play an important role in the precipitation mechanisms in regions where biomass burning contributes significantly to the total aerosol mass (MayolBracero et al., 2002a; Mircea et al., 2005). During the LBASMOCC-2002 campaign, Hoffer and collaborators (2006b) characterized the total carbon (TC) and WSOC from fine bulk samples in order to measure the high-molecular weight carbon (HMWC) compounds. They found that the HMWC dominated the TC composition. Diel variations in anhydrosugars and phenolic acids suggested that the phenolic acids may undergo chemical transformations towards more refractory compounds, as was also implied previously for HULIS.

There are very few studies that present size-resolved information about the carbonaceous fractions during biomass burning at tropical locations (e.g., Echalar et al., 1998; Falkovich et al., 2005; Decesari et al., 2006). Size-resolved $\mathrm{EC} / \mathrm{BC}$ and $\mathrm{OC}$ information is important since it provides a better understanding of the lifetimes and optical properties of these species. In the Amazon Basin, prior to LBASMOCC-2002, the only study was the one by Echalar et al. (1998), which reported size-resolved BC concentrations, having determined $\mathrm{BC}$ using a light reflectance technique. To our knowledge, ours is the first study that presents both $\mathrm{EC}_{\mathrm{a}}$ and $\mathrm{OC}$ size distributions for the dry season in the Amazon Basin. This type of study is essential for improving our understanding of the climate impact of $\mathrm{BC}$ or EC, species whose climatic effects strongly depend on their physical and chemical properties, as well as on their residence time and distribution in the atmosphere (Jacobson, 2001; Novakov et al., 2005). Herckes et al. (2006) reported OC and molecular source marker species size distributions from biomass burning at the Yosemite National Park, CA. This study showed that more than $75 \%$ of the OC mass and most of the molecular marker species were associated with fine aerosol particles. Falkovich and collaborators (2005) studied the lowmolecular-weight (LMW) organic acids in aerosol particles using a cascade impactor with eleven stages (Micro Orifice Uniform Deposit Impactor - MOUDI) during SMOCC2002. They found that LMW polar organic acids, which may contribute to the CCN activity, accounted for a significant fraction of the WSOC in biomass burning aerosols (10$20 \%$ ). Also, Fuzzi and collaborators (2007), during the same campaign, presented an overview of the size-segregated inorganic and organic results from different cascade impactor samplers. This study characterized organic material (mainly water-soluble), ions, and mineral dust. During the dry period, the average mass concentration of particulate matter with a diameter below $10 \mu \mathrm{m}\left(\mathrm{PM}_{10}\right)$ was above $50 \mu \mathrm{g} \mathrm{m}^{-3}$. The size distributions were dominated by the fine mode, which was mainly composed of organic material, mostly watersoluble, and had $\sim 10 \%$ soluble inorganic salts, with sulfate as the major anion. Decesari et al. (2006) employed different techniques for individual compound analysis in order to speciate the aerosol organic compounds during SMOCC-2002. In that study, up to $8 \%$ of the submicron TC (and $11 \%$ of WSOC) was speciated at the molecular level. Polyhydroxylated compounds, aliphatic and aromatic acids were the main classes. Characterizations of 50-90\% of the WSOC into neutral species, light acids, and humic-like substances were also made. The size-segregated composition of WSOC was summarized by a set of model compounds, which represent both the organic compound composition and the functional groups of the WSOC. With this information one was able to predict the aerosol hygroscopic properties and $\mathrm{CCN}$ ability over Amazonia (Mircea et al., 2005).

To our knowledge, a study presenting the size-resolved carbonaceous components (i.e., OC and EC) of biomassburning dominated aerosols in the Amazon Basin has not been reported. One of the reasons for this is the difficulty in distinguishing OC from EC in biomass burning samples using the commonly used thermal analytical techniques (Gundel et al., 1984; Novakov and Corrigan, 1995; MayolBracero et al., 2002a; Pöschl, 2003; Andreae and Gelencsér, 2006).

Thermal analyses of the carbonaceous fraction from aerosol samples allow the determination of $\mathrm{OC}$ and $\mathrm{EC}_{\mathrm{a}}$. Apparent elemental carbon $\left(\mathrm{EC}_{\mathrm{a}}\right)$ is operationally defined as the fraction of carbon that is oxidized above certain temperature threshold in the presence of an oxygen-containing atmosphere (Andreae and Gelencsér, 2006). Various corrections for charring are usually made, depending on the specific technique used (Chow et al., 1993, 2001, 2004, 2007, NIOSH, 1996, 1999; Zhen et al., 2002). OC is defined as TC 
minus the sum of carbonate and $\mathrm{EC}_{\mathrm{a}}$. A related parameter, equivalent black carbon $\left(\mathrm{BC}_{\mathrm{e}}\right)$ is defined as the amount of strongly light-absorbing carbon with the approximate optical properties of soot carbon $\left(\mathrm{C}_{\mathrm{soot}}\right)$ that would give the same signal in an optical instrument (e.g., in the light transmission method) as the sample. These definitions of $\mathrm{EC}_{\mathrm{a}}$ and $\mathrm{BC}_{\mathrm{e}}$ are operational and method dependent, and are used as approximations for the concentration of light absorbing carbon (LAC) or $\mathrm{C}_{\text {soot }}$ (Andreae and Gelencsér, 2006). $\mathrm{C}_{\text {soot }}$ refers to carbon particles with the morphological and chemical properties typical of soot particles from combustion: Aggregates of spherules made of graphene layers, consisting almost purely of carbon, with minor amounts of bound heteroelements, especially hydrogen and oxygen. This definition does not include the organic substances (oils, etc.) frequently present in, or on, combustion particles. Together with lightabsorbing organic compounds (also called "brown carbon"), $\mathrm{C}_{\text {soot }}$ makes up the LAC fraction of the atmospheric aerosol.

For biomass burning samples, there is no sharp boundary for differentiating $\mathrm{OC}$ from $\mathrm{EC}_{\mathrm{a}}$, due to the presence of $\mathrm{OC}$ material that is highly refractory and optically absorbing, like brown carbon and humic-like substances (Pöschl, 2003; Hoffer et al., 2006a; Hoffer et al., 2006b; Andreae and Gelencsér, 2006). The results obtained by different authors and different techniques can therefore vary dramatically, especially for $\mathrm{EC}_{\mathrm{a}}$, as a result of different analytical protocols (Novakov and Corrigan, 1995; Mayol-Bracero et al., 2002a; Kirchstetter et al., 2003, Watson et al., 2005).

In this paper, we present the size-resolved concentrations of carbonaceous aerosol particles collected at a pasture site in Rondônia, Brazil, during the biomass-burning dominated part of the SMOCC-2002 campaign, giving special attention to the determination of $\mathrm{EC}_{\mathrm{a}}$ or $\mathrm{BC}_{\mathrm{e}}$ using several thermal and optical methods.

\section{Experimental}

\subsection{Sampling site and experimental setup}

The sampling site was located on a pasture of the ranch Fazenda Nossa Senhora Aparecida (FNS) in the Brazilian Amazon $\left(10^{\circ} 45^{\prime} 44^{\prime \prime} \mathrm{S}, 62^{\circ} 21^{\prime} 27^{\prime \prime} \mathrm{W}\right)$ near the town of Ouro Preto D'Oeste, Rondônia, Brazil. Sample collection took place during the September-October 2002 burning period. This site has experienced intense deforestation by vegetation fires over the last 30 years (Andreae et al., 2002; Kirkman et al., 2002; Trebs et al., 2005). Maps of the fire locations in Fuzzi et al. (2007) clearly show that the sampling site was under the influence of emissions from fires extending to $2000 \mathrm{~km}$ upwind of the site during the sampling period. Also there was local burning nearby, which was particularly an influence at night-time because of the trapping of smoke in the nocturnal boundary layer.

\subsubsection{Dekati low-pressure impactor}

Aerosol samples were collected with a 13-stage Dekati low-pressure impactor (DLPI) which separates particles according to their particle aerodynamic diameter $\left(D_{p}\right)$ (from $\sim 10 \mu \mathrm{m}$ down to $30 \mathrm{~nm}$ ). The DLPI was placed on a tower at a height of $\sim 8 \mathrm{~m}$. Size-resolved particles were collected on quartz fiber filters (Pallflex Membrane FilterTissuquartz 2500 QAT-UP) and Teflon filters (Pall Teflo ${ }^{\mathrm{TM}}$ $3.0 \mu \mathrm{m}$ ) and on aluminum substrates (MSP Corporationaluminum foil impaction substrates, 2 mask, MDI-225). One half of each substrate was analyzed using evolved gas analysis (EGA) and the other half using ion chromatography (IC) and/or inductively coupled plasma (ICP) with optical emission spectroscopy (OES). Samples were collected during day and/or night for 12 or $24 \mathrm{~h}$. The sampling flow averaged $291 \mathrm{~min}^{-1}$ and the pressure $250 \mathrm{hPa}$. Sampled volumes averaged $\sim 16 \mathrm{~m}^{3}$ and $36 \mathrm{~m}^{3}$, respectively, and these were converted to standard temperature $\left(25^{\circ} \mathrm{C}\right)$ and pressure $(1000 \mathrm{hPa})$.

The apparent size range collected on each stage was calculated depending on the DLPI pressure and flow. However, size biases in the DLPI may result from the use of nonstandard substrate materials. The reason for this is briefly described here.The DLPI size distributions measured using quartz fiber substrates differ from the nominal ones, since for the standard DLPI impactors the aerodynamic diameter calculated for each stage is calibrated using smooth and flat surfaces, which are quite different from the surface characteristics of the quartz fiber filters. The use of these filters introduces differences due to the different flow rates and sampling mechanism (i.e., impaction together with filtration) (Hitzenberger et al., 2004; Saarikoski et al., 2008). Therefore, the $D_{p}$ values and the shape of the collection efficiency curves may change, as has been shown by Saarikoski et al. (2008). As a result, the carbonaceous size distributions presented in this study are expected to be shifted toward larger apparent diameters when using quartz filters. More accurate DLPI size distributions could have been obtained by performing an inversion procedure (e.g., Bayesian inversion method (Ramachandran and Kandlikar, 1996), a bimodal lognormal function constructed by Dong et al. (2004), or a lognormal function for porous substrates suggested by Marjamäki et al., 2005), but the experimental data necessary to apply this procedure (i.e., calibration of impactor stage collection efficiencies, and the mathematical model function) are not available for the DLPI.

Blanks were collected using quartz fiber and aluminum substrates on the DLPI sampler in the same way as real samples were taken, but with flow being applied only for about $5 \mathrm{~s}$. It should be noted that $5 \mathrm{~s}$ is too short a time to represent passive vapor adsorption (Watson et al., 2009). The quartz fiber filters were pre-baked at $600^{\circ} \mathrm{C}$ for about $15 \mathrm{~h}$ to remove residual organic impurities. After collecting the samples, they were stored in a freezer at $-18^{\circ} \mathrm{C}$ in Petrislide 
dishes (Millipore, $47 \mathrm{~mm}$ Petrislide, PD1504700) until analysis. Handling of filters was according to the procedures recommended by Salmon et al. (1998) and Mayol-Bracero et al. (2002a).

A complete assessment of corrections for positive artifacts (overestimation of carbonaceous particle concentration due to adsorption of organic gases to the quartz filters) and negative artifacts (underestimation of carbonaceous particles due to volatilization of semi-volatile organic carbon from the particles collected on the filters) was not possible in this study because our sampling systems did not provide for this. However, an estimation of the positive artifact for the DLPI was performed by comparing TC concentrations measured with other filter samplers (Sect. 3.1.3). The positive artifact during SMOCC-2002 was determined with the HVDS. The OC was measured on the back filter placed in a tandem position. This back filter OC could come from both positive and negative artifacts (Mader et al., 2003). However, it is generally assumed that the positive artifacts prevail (Turpin et al., 2000; Mader et al, 2003); therefore, OC (front) - OC (back) is considered a measure for "artifact-free" particulate OC. On the other hand, we could assume that the positive artifacts are negligible and that the back filter OC is actually due to negative artifacts ( $\mathrm{OC}$ that was volatilized from the front filter). If this was the case, OC (front) + OC (back) would be a measure for "artifact-free" particulate OC. One problem with the latter approach is that the OC that is lost (by volatilization) from the front filter may not be fully captured by the back filter. There are certainly better approaches to assess the extent of negative artifacts, as proposed by Eatough et al. (2003), but they were not used in SMOCC-2002.

In Sect. 3 we compare the results obtained with (1) the DLPI used by University of Puerto Rico (UPR), (2) a low-volume $\mathrm{PM}_{2.5}$ filter sampler used by Ghent University (R2.5WW UGent), (3) three high-volume dichotomous samplers (HVDS), (4) a carbon monitor operated by the University of São Paulo (USP), and (5) a 7-wavelength aethalometer from USP (Hansen et al., 1984), all located at FNS during the SMOCC-2002 experiment. Two of the HVDSs were used by UGent (Decesari et al., 2006) and the other by the Max Planck Institute for Chemistry (MPIC) (Hoffer et al., 2006b). A brief description of these systems is presented below.

\subsubsection{Low-volume $\mathbf{P M}_{2.5}$ filter sampler (R2.5WW) and High-Volume Dichotomous Samplers (HVDS)}

The low-volume $\mathrm{PM}_{2.5}$ filter sampler (R2.5WW) is a filter holder with 47-mm diameter filters; it was equipped with a Rupprecht \& Patashnick $\mathrm{PM}_{2.5}$ inlet and operated at a flow rate of $171 \mathrm{~min}^{-1}$; the face velocity was $22 \mathrm{~cm} \mathrm{~s}^{-1}$ and the air volume was measured with a calibrated gas meter. The HVDS is a system that separates bulk particles into fine $\left(D_{p}<\sim 2.5 \mu \mathrm{m}\right)$ and coarse $\left(D_{p}>\sim 2.5 \mu \mathrm{m}\right)$ (Solomon et al., 1983). The filter diameter was $102 \mathrm{~mm}$ with a face velocity of about $86 \mathrm{~cm} \mathrm{~s}^{-1}$ for a total average flow of about
$3301 \mathrm{~min}^{-1}$. The sampling periods were $12 \mathrm{~h}$ each during day time night time in the dry period. Samples were collected with quartz fiber filters (Whatman QM-A for the R2.5WW, Gelman Pall for the HVDS), pre-baked for at least $10 \mathrm{~h}$ at $600^{\circ} \mathrm{C}$. In both the R2.5WW and the HVDS, two quartz fiber filters were placed in the filter holders in tandem in order to correct for the adsorption of gaseous organic compounds by the filter material (i.e., positive artifact).

\subsubsection{Carbon monitor and aethalometer}

The carbon monitor (Model 5400, Rupprecht \& Patashnick, Inc.) is an on-line instrument that collects ambient air particles by impaction in order to make hourly measurements of carbonaceous aerosol components (TC, $\mathrm{OC}$, and $\mathrm{EC}_{\mathrm{a}}$ ). The $\mathrm{OC}$ component is the carbon content burned off when a controlled combustion at $350^{\circ} \mathrm{C}$ is applied. TC is obtained by combusting the aerosol at $700^{\circ} \mathrm{C}$, and $\mathrm{EC}_{\mathrm{a}}$ is derived as the difference between TC and OC (Artaxo et al., 2002). Since aerosols were collected by impaction, particles smaller than $70 \mathrm{~nm}$ may not have been collected efficiently. Because the impaction surfaces were not coated (to avoid organic contamination), bounce-off from the impaction surface could have occurred for dry periods.

The aethalometer (AE30, Magee Scientific) is also an on-line device, used to measure equivalent black carbon $\left(\mathrm{BC}_{\mathrm{e}}\right)$. It was operated with a 5-min time resolution, and a specific absorption cross section of $16.6 \mathrm{~m}^{2} \mathrm{~g}^{-1}$ at $880 \mathrm{~nm}$ was used to convert optical absorption to $\mathrm{BC}_{\mathrm{e}}$ (Park et al., 2006). Absorption measurements from the aethalometer agreed well with Nuclepore filter based measurements using a calibrated black carbon standard (Martins et al., 1998a, b). Results from the aethalometer also agreed within $30 \%$ with a multi angle absorption photometer, taking into account the different wavelengths used (Hansen et al., 1984; Schmid et al., 2006). In addition, the aethalometer results were subjected to artifact corrections for filter loading and multiple scattering given by Weingartner et al. (2003) and Schmid et al. (2006). Briefly, from the equivalent black carbon mass concentration reported by the aethalometer and the specific absorption cross section of $14625 / \lambda\left(\mathrm{m}^{2} \mathrm{~g}^{-1}\right)$ $\left(16.6 \mathrm{~m}^{2} \mathrm{~g}^{-1}\right.$ for $\left.880 \mathrm{~nm}\right)$ the attenuation coefficient $\sigma_{\mathrm{ATN}}$ was calculated using the equation $\sigma_{\mathrm{ATN}}=\mathrm{BC}_{\mathrm{e}} * 16.6$. The absorption coefficients $\sigma_{\text {abs }}$ were obtained by applying corrections given in Weingartner et al. (2003): $\sigma_{\mathrm{abs}}=$ $\sigma_{\mathrm{ATN}} /(\mathrm{C} \cdot R(\mathrm{ATN}))\left(\mathrm{Mm}^{-1}\right)$, were $R(\mathrm{ATN})$ accounts for the reduction of the optical path length in the filter with increasing filter load and $C$ corrects for the multiple scattering effects of the filter fibers. The filter loading correction equation used was: $R=(1 / f-1)(\ln A T N-\ln 10) /(\ln 50-\ln 10)+$ 1 (Weingartner et al., 2003), where $f=1.2$ during the SMOCC-2002 campaign (Schmid et al., 2006). The equation for the wavelength-dependent multiple scattering $C_{\lambda} / C_{\lambda 0}=$

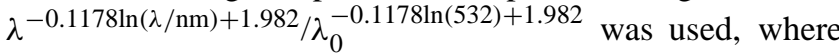
$C$ at $880 \mathrm{~nm}$ is equal to 6.54 (Schmid et al., 2006). After 
applying the corrections, corrected $\mathrm{BC}_{\mathrm{e}}$ was calculated using the absorption cross section $\alpha_{\mathrm{abs}}$ of soot carbon at $880 \mathrm{~nm}$ $\left(4127 / \lambda\left(\mathrm{m}^{2} \mathrm{~g}^{-1}\right)=4.69\right.$ at $\left.880 \mathrm{~nm}\right)$ as follows: $\mathrm{BC}_{\mathrm{e} \text { corr }}=$ $\sigma_{\text {abs }} * 1000 / \alpha_{\text {abs }}$. Concentrations were not corrected for the sampling spot size and changes in flow rate of the instrument (Müller et al., 2011). These corrections are likely to be small in comparison to the other uncertainties.

\subsection{Aerosol mass concentration}

The mass collected on the aluminum substrates was determined by gravimetric analysis, which involved weighing the aluminum substrates before and after sampling using a Mettler MT5 microbalance ( $1 \mu \mathrm{g}$ sensitivity) in a room with stabilized temperature $\left(20^{\circ} \mathrm{C}\right)$ and relative humidity $(50 \%)$. For more details see Hitzenberger et al. (2004).

\subsection{Chemical analyses}

The analyses presented here are for the bulk and the sizeresolved concentrations of carbonaceous components. These concentrations were determined for sections of the lowvolume filter sampler, HVDS, DLPI quartz filters and the aluminum substrates, using thermal, thermal-optical transmission (TOT) and reflectance (TOR) methods, thermal-optical analysis (TOA), and a light transmission method (LTM). Results from IC and ICP analyses of the inorganic fraction were also included.

\subsubsection{Thermal and thermal-optical analysis}

A thermal analysis method (evolved gas analysis (EGA)) similar to that described by Novakov (1981) and Kirchstetter et al. (2001) was used at Lawrence Berkeley National Laboratory (LBNL) and MPIC to characterize TC, $\mathrm{EC}_{\mathrm{a}}$ and OC. Segments of 0.55 or $1.8 \mathrm{~cm}^{2}$ were taken from the $3.63 \mathrm{~cm}^{2}$ exposed area of a $25 \mathrm{~mm}$ diameter quartz filter and heated in an oxygen atmosphere at a rate of $\sim 20^{\circ} \mathrm{C}$ per min from $50^{\circ} \mathrm{C}$ to $\sim 700^{\circ} \mathrm{C}$. The evolved carbon was converted to $\mathrm{CO}_{2}$ over a Pt-coated ceramic (at LBNL) or $\mathrm{MnO}_{2}$ (at MPIC) catalyst $\left(\right.$ at $800^{\circ} \mathrm{C}$ ) and measured by a non-dispersive infrared analyzer. Evolved carbon (as $\mathrm{CO}_{2}$ concentration) was plotted as a function of temperature (i.e., a thermogram). Thermogram peaks indicate carbon volatilization, decomposition, and combustion. The area under the whole thermogram is proportional to the mass of sampled TC. We defined the "apparent elemental carbon" $\left(\mathrm{EC}_{\mathrm{a}}\right)$ as the portion of the sample evolving above $400{ }^{\circ} \mathrm{C}$. OC was calculated using the equation $\mathrm{OC}=\mathrm{TC}-\mathrm{EC}_{\mathrm{a}}$.

To refine the estimate of $\mathrm{EC}_{\mathrm{a}}$, and consequently $\mathrm{OC}$, the intensity of light (at $572 \mathrm{~nm}$ ) transmitted through the sample was monitored during the thermal analysis. Here we refer to the combination of the thermal and light transmission methods as thermal-optical analysis (TOA). The 572$\mathrm{nm}$ light was generated with a light emitting diode, and the intensity transmitted through the samples was measured with a spectrometer. For additional details see Kirchstetter and Novakov (2007).

Portions of some samples were soaked in $10-15 \mathrm{~mL}$ of ultrapurified water for $30 \mathrm{~min}$ to extract water-soluble organics and then dried under an infrared lamp prior to analysis.

The thermal method was quantitative for TC to within $\sim 10 \%$, with a reproducibility of $5 \%$, and a detection limit of $\sim 0.2 \mu$ g per sample (Dod et al., 1979; Gundel et al., 1984). The precision or coefficient of variation (CV) for this method was $4,6,4$, and $3 \%$ for $\mathrm{TC}, \mathrm{EC}_{\mathrm{a}}$, OC, and the $\mathrm{EC}_{\mathrm{a}} / \mathrm{OC}$ ratio, respectively (Mayol-Bracero et al., 2002b).

\subsubsection{Thermal optical reflectance (TOR) and transmission (TOT) method}

IMPROVE-TOR and IMPROVE-TOT were used at DRI and NIOSH-TOT at the UGent to determine the concentration of $\mathrm{TC}$ and $\mathrm{EC}_{\mathrm{a}}$. These techniques have been described elsewhere (Chow et al., 1993; Birch and Cary, 1996; Peterson and Richards, 2002; Chen et al., 2004). Briefly, a small sample segment of the filter is taken from a quartz-fiber filter and analyzed. The carbon evolved from the filter is measured with a thermal-optical analyzer, using two heating temperature profiles, one with $100 \% \mathrm{He}$ and the other with $98 \%$ $\mathrm{He} / 2 \% \mathrm{O}_{2}$. The evolving carbon is oxidized to $\mathrm{CO}_{2}$, the $\mathrm{CO}_{2}$ is reduced to $\mathrm{CH}_{4}$, and the $\mathrm{CH}_{4}$ is measured using a flame ionization detector. Both methods (TOT and TOR) have a $\mathrm{He} / \mathrm{Ne}$ laser beam (at $632 \mathrm{~nm}$ ) that is directed on the filter and the direct forward (TOT) and/or backward (TOR) scattering of the radiation is detected by photo-detectors to measure reflectance and transmittance throughout the analysis. This arrangement is used for the correction of the charring effect.

\subsubsection{Light Transmission Method (LTM)}

Samples collected on quartz fiber filters were analyzed using the light transmission method (LTM) (Kirchstetter et al., 2004). Light attenuation (ATN) was calculated from light transmission through the sample $(T)$ : ATN $=100 \cdot \ln (1 / \mathrm{T})$. In this study, $T$ was defined as $\left(I_{\mathrm{S}} / I_{\mathrm{S}, \mathrm{o}}\right) \cdot\left(I_{\mathrm{r}, \mathrm{o}} / I_{\mathrm{r}}\right)$, where $I_{\mathrm{S}}$ and $I_{\mathrm{s}, \mathrm{o}}$ are the measured intensities of light transmitted through a quartz fiber filter sample prior to and after removal of carbonaceous material by heating to $700{ }^{\circ} \mathrm{C}$ in oxygen, and $I_{\mathrm{r}}$ and $I_{\mathrm{r}, \mathrm{o}}$ are the intensities of light transmitted through a reference quartz filter measured at the same time as $I_{\mathrm{S}}$ and $I_{\mathrm{s}, \mathrm{o}}$. The intensities $I_{\mathrm{S}}$ and $I_{\mathrm{S}, \mathrm{o}}$ were measured using the same quartz filter rather than another blank, because light transmission through quartz fiber filters is variable. Measuring $I_{\mathrm{S}, \mathrm{o}}$ on the same filter also automatically corrects for the absorption due to mineral dust, because light-absorbing dust is not removed during sample heating. In this study, we only wanted to measure aerosol ATN due to carbonaceous material, and not mineral dust.

The reference filter was used to correct for possible instrumental variability such as changes in the brightness of the 
light source or detector response during the interval between measurements of $I_{\mathrm{S}}$ and $I_{\mathrm{S}, \mathrm{o}}$. The uncertainty of each measurement when using the LTM was $\sim \pm 2$ units of ATN.

Mass concentrations of $\mathrm{BC}_{\mathrm{e}}$ at $880 \mathrm{~nm}$ were estimated from LTM data, following the method used for the aethalometer (Hansen et al., 1984): $\mathrm{BC}_{\mathrm{e}}=\mathrm{ATN} / \sigma$, where $\sigma$ is the specific attenuation (or specific absorption cross section) for BC and ATN is light attenuation at $880 \mathrm{~nm}$ by particles on the quartz fiber filters. In order to be able to compare $\mathrm{BC}_{\mathrm{e}}$ concentration obtained from the LTM and the aethalometer, a specific absorption cross section of $16.6 \mathrm{~m}^{2} \mathrm{~g}^{-1}$ was used for both instruments.

\subsubsection{Ion Chromatography (IC) and Inductively Coupled Plasma (ICP)}

Mass concentrations of inorganic species were determined using IC and ICP analysis. Water-soluble ions were determined using isocratic suppressed IC with conductivity detection (DIONEX, Sunnyvale, Ca). The anionic species measured were $\mathrm{Cl}^{-}, \mathrm{SO}_{4}^{2-}$, and $\mathrm{NO}_{3}^{-}$, and the cationic species were $\mathrm{NH}_{4}^{+}, \mathrm{Ca}^{2+}, \mathrm{Mg}^{2+}, \mathrm{K}^{+}$, and $\mathrm{Na}^{+}$. Filters and substrates were cut in halves and extracted with methanol and/or ultrapure water. ICP together with optical emission spectroscopy (OES) was also used for the determination of trace elements, such as $\mathrm{Al}, \mathrm{B}, \mathrm{Ca}, \mathrm{Fe}, \mathrm{K}, \mathrm{Mg}, \mathrm{Mn}, \mathrm{Na}, \mathrm{Si}$, and $\mathrm{Zn}$, in the extracted water from the filters and substrates.

\section{Results and discussion}

Concentrations of carbonaceous species determined by thermal, thermal-optical, and optical analyses are reported in Table 1. From samples analyzed thermally we estimated $\mathrm{TC}$ and $\mathrm{EC}_{\mathrm{a}}$ concentrations. Samples extracted with water and analyzed using TOA (DLPI \#11, 13, and 15) provided $\mathrm{TC}$ and $\mathrm{EC}_{\mathrm{w}}$ (EC from these analyses is called $\mathrm{EC}_{\mathrm{w} 572 \mathrm{~nm}}$ ) concentrations. Samples analyzed by the light transmission method (LTM) (DLPI \#3, 11, 12, 13, 15, and 25) provided $\mathrm{BC}_{e}$ at $880 \mathrm{~nm}\left(\mathrm{BC}_{\mathrm{e}} 880 \mathrm{~nm}\right)$. Below we explain how these different carbonaceous components were determined.

\subsection{Estimation of the carbonaceous material}

\subsubsection{Mass and total carbon concentrations}

Particle mass concentrations for the fine $\left(D_{p}<2.5 \mu \mathrm{m}\right)$ and coarse $\left(D_{p}>2.5 \mu \mathrm{m}\right)$ fractions were determined gravimetrically from samples collected on aluminum and Teflon substrates. The average fine particle mass concentration for the dry period from 7 September to 7 October was $60 \mu \mathrm{g} \mathrm{m}^{-3}$ (with a standard deviation (STDEV) of $\pm 41 \mu \mathrm{g} \mathrm{m}^{-3}$ ), consistent with elevated concentrations reported by Fuzzi et al. (2007). These high concentrations were due to the huge burning areas upwind over which the sampled air masses had traveled for several days, and due to the dynamics of

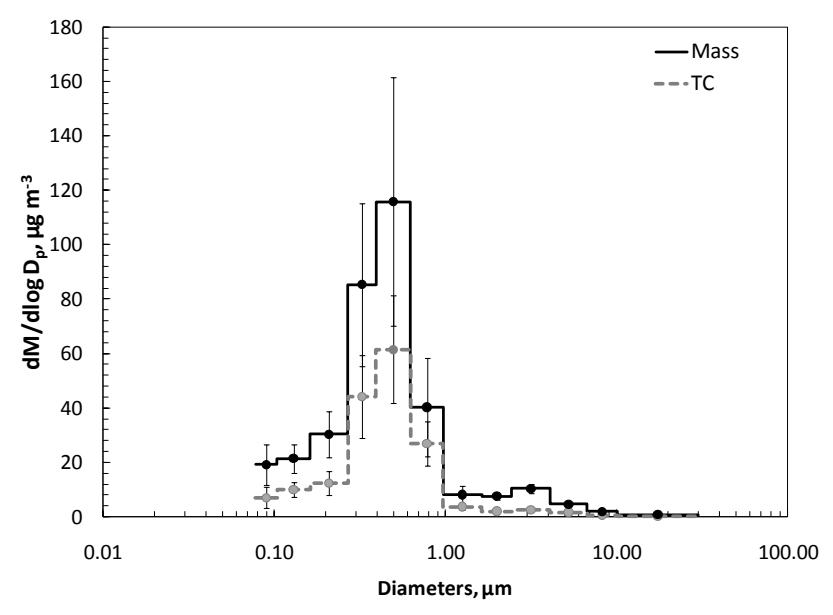

Fig. 1. Average particulate mass and TC size distributions during the dry period. The size distribution for the mass and TC concentrations are the average for all samples collected on aluminum foil substrates during the dry period $(n=6)$. Error bars represent the standard error (standard deviation divided by the number of samples).

the boundary layer (Fuzzi et al., 2007; Rissler et al., 2006). During the transition period from 7 October to 1 November and the wet period in the first four days of November, the average concentrations of the fine fraction were 15 $( \pm 12) \mu \mathrm{g} \mathrm{m}^{-3}$ and $4( \pm 2) \mu \mathrm{g} \mathrm{m}^{-3}$, respectively. The average coarse particle concentrations were relatively constant at 4 $( \pm 2) \mu \mathrm{g} \mathrm{m}^{-3}$ during the entire period. TC concentrations in the fine aerosol fraction ranged from 24 to $64 \mu \mathrm{g} \mathrm{m}^{-3}$ and averaged $44 \mu \mathrm{g} \mathrm{m}^{-3}$ (Table 1 ). These concentrations are within the range of values observed for bulk analyses in a previous campaign at the same site during the dry season, where TC ranged between 4.4 and $83 \mu \mathrm{g} \mathrm{m}^{-3}$ (Graham et al., 2002; Mayol-Bracero et al., 2002a). Similar concentrations were observed in the results from other filter sampling systems during SMOCC-2002, with concentrations ranging from 6.4 to $78.2 \mu \mathrm{g} \mathrm{m}^{-3}$ (average $32.7 \mu \mathrm{g} \mathrm{m}^{-3}, \mathrm{HVDS}_{\mathrm{UGent}}$ ) and 24.9

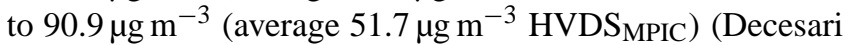
et al., 2006), showing $\sim 30 \%$ difference from our average TC value.

The average size-resolved concentrations for total particulate mass and TC are presented in Fig. 1. Both size distributions were bimodal, peaking in the accumulation $(0.4-$ $0.6 \mu \mathrm{m})$ and coarse modes $(1.6-2.4 \mu \mathrm{m})$. The average TC/PM ratios from the aluminum substrate samples for the fine and coarse fractions were $0.56 \pm 0.08$ and $0.31 \pm 0.09$, respectively. These results indicate that the carbon content was higher in the fine aerosol fraction than in the coarse fraction. As suggested previously, biogenic and inorganic crustal material might be found in the coarse particles (Fuzzi et al., 2007).

We do not follow this discussion directly with the results of the $\mathrm{EC} / \mathrm{BC}$ and $\mathrm{OC}$ size distributions, because in order to present the best possible $\mathrm{EC} / \mathrm{BC}$ and $\mathrm{OC}$ concentrations 

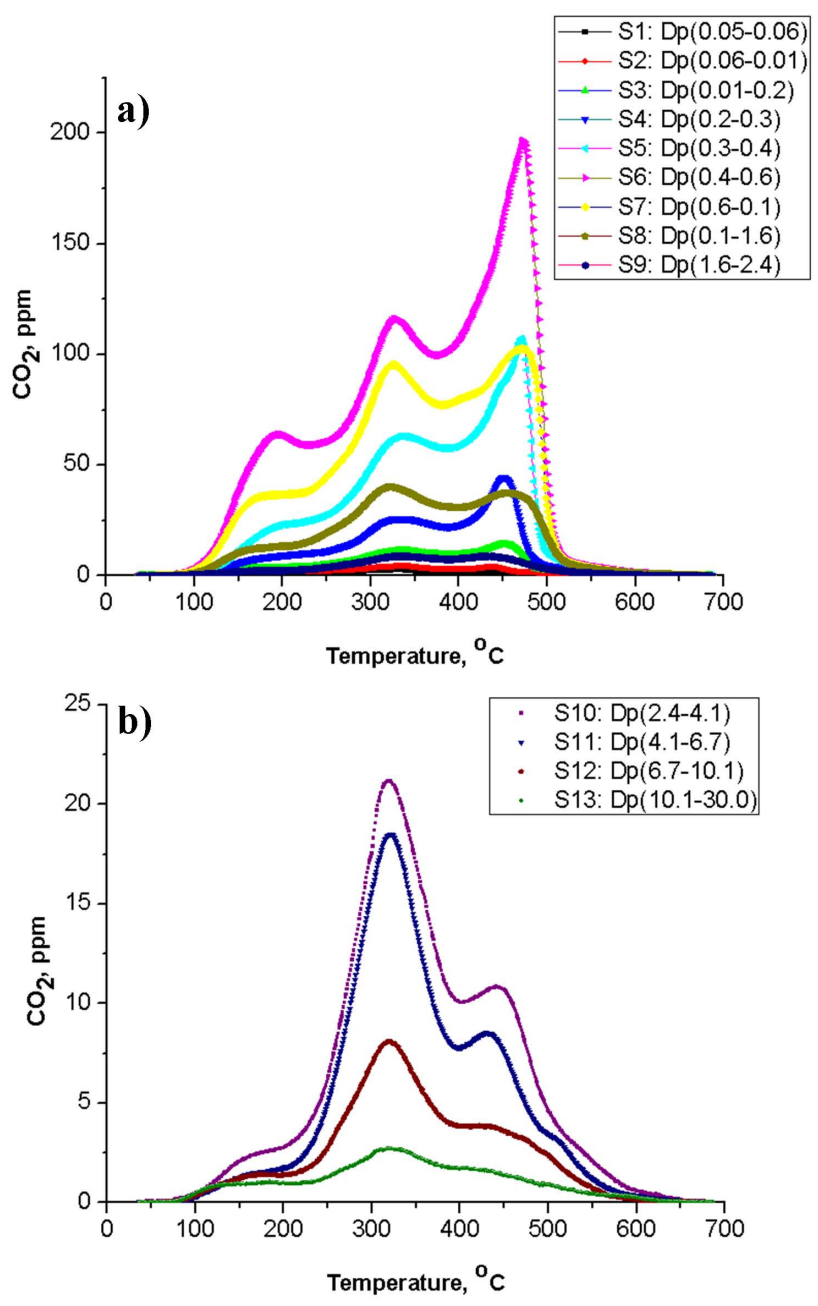

Fig. 2. Typical thermograms determined by EGA showing the thermal characteristics of size-resolved aerosol samples from biomass burning for one set of samples (DLPI\#25): evolved carbon $\left(\mathrm{CO}_{2}\right.$, $\mathrm{ppm}$ ) versus temperature. There are three distinguishable peaks indicating different volatilities and/or reactivities. (a) Fine particles. The last peak is dominant (less volatile and highly refractory). (b) Coarse particles. The first two peaks are relatively larger.

we must first evaluate the possible methods to measure these species and determine the most appropriate one. This evaluation is performed in the following sections, and at the very end of the discussion of the results, the size distributions of $\mathrm{EC} / \mathrm{BC}$ and $\mathrm{OC}$ are presented.

\subsubsection{Light absorbing carbon}

Figure 2 presents the size-resolved thermograms from aerosols collected during SMOCC-2002 that were dominated by biomass burning emissions. The thermograms generally had two or three different peaks: those below $400^{\circ} \mathrm{C}$ were attributed to $\mathrm{OC}$ and the peak above $400^{\circ} \mathrm{C}$ corresponded to $\mathrm{EC}_{\mathrm{a}}$, the most refractory material. Concentra-
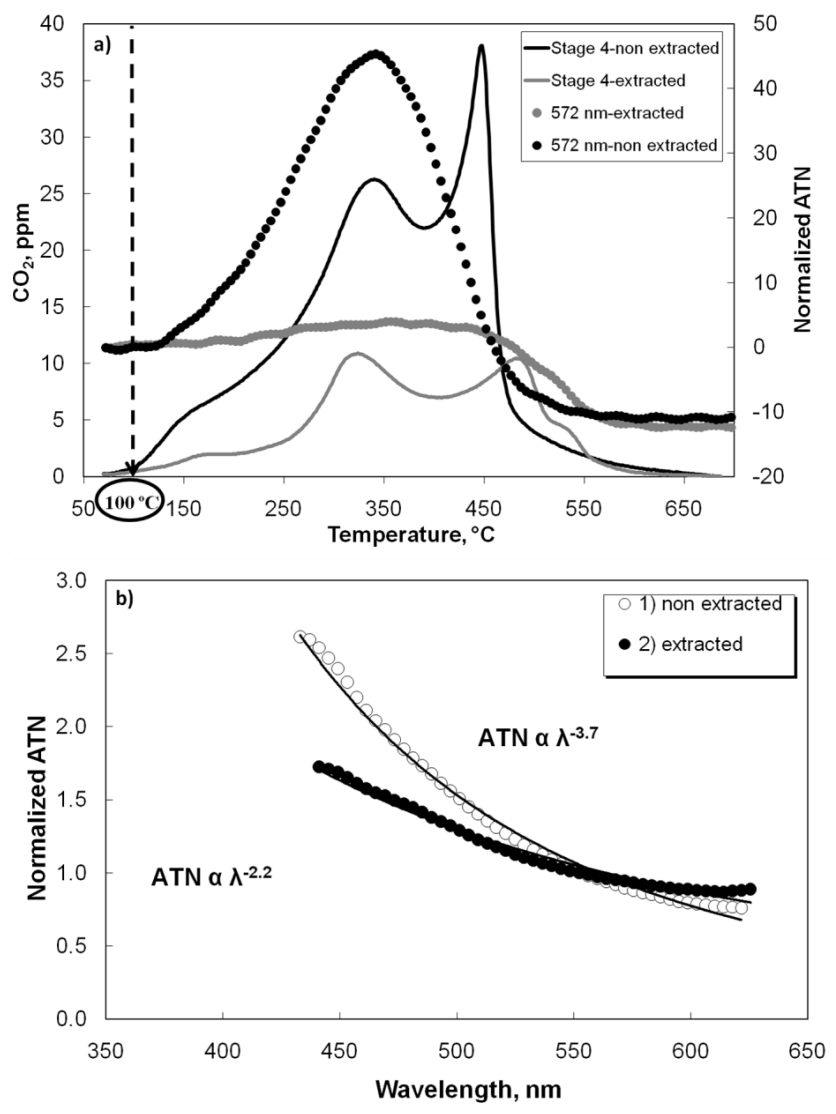

Fig. 3. (a) Thermal-optical analysis of quartz fiber filter samples (water extracted and non-extracted), (b) The spectral attenuation (normalized ATN) measured at $100^{\circ} \mathrm{C}$ for DLPI\#11-stage $4\left(D_{p}\right.$ : $0.2-0.3 \mu \mathrm{m})$.

tions of $\mathrm{EC}_{\mathrm{a}}$ averaged $18( \pm 9) \mu \mathrm{g} \mathrm{m}^{-3}$ in the fine particle mode $\left(D_{p}<2.5 \mu \mathrm{m}\right)$. Uncertainties exist in the determination of $\mathrm{EC}_{\mathrm{a}}$, especially for biomass burning aerosols (Pöschl, 2003; Hoffer et al., 2006a; Hoffer et al., 2006b; Andreae and Gelencsér, 2006). During the thermal analysis of biomass aerosols, some OC in the aerosol surface deposit and in organic vapors adsorbed throughout the filter turns into char as it undergoes pyrolysis; this char co-evolves with EC. Also, some highly refractory $\mathrm{OC}$ in biomass aerosols co-evolves with EC and might be indistinguishable from it (Hoffer et al., 2006b).

In this study, we examined how optical and solvent extraction techniques can be used in addition to thermal analysis to obtain a better estimation of EC in biomass aerosol samples. Figure 3 shows the thermograms from DLPI\#11-stage 4 (nominal $D_{p}$ from $0.2-0.3 \mu \mathrm{m}$ ) before and after extracting with water. Water extraction removed large quantities of OC ( $\sim 60 \%$ for the fine fraction), and the amount of $\mathrm{EC}_{\mathrm{a}}$ lost was $\sim 50 \%$. For similar samples, Mayol-Bracero et al. (2002) found that on average $53 \%$ of the $\mathrm{EC}_{\mathrm{a}}$ was removed by water extraction. The reduction in $\mathrm{EC}_{\mathrm{a}}$ was due to the removal 
Table 1. Concentration of the size-resolved carbonaceous components collected at the pasture site (FNS) during the dry period for the LBASMOCC-2002 campaign using different methods (EGA, LTM and aethalometer). All concentrations are given in $\mu \mathrm{g} \mathrm{m}{ }^{-3}$. NM indicates not measured and STDEV refers to the standard deviaton of the average. The last column is for the equivalent black carbon $\left(\mathrm{BC}_{\mathrm{e}}\right)$ for particles with $D_{p}<10 \mu \mathrm{m}$ measured by the aethalometer at $880 \mathrm{~nm}$ and corrected for the filter loading and multiple scattering artifacts.

\begin{tabular}{|c|c|c|c|c|c|c|c|c|c|c|c|c|c|c|c|}
\hline \multicolumn{5}{|c|}{$\begin{array}{l}\text { Method } \\
\text { used } \Longrightarrow\end{array}$} & \multicolumn{7}{|c|}{ EGA* $^{*}$} & \multicolumn{3}{|c|}{ LTM $^{* *}$} & \multirow{2}{*}{$\begin{array}{l}\text { Aethalometer } \\
\mathrm{BC}_{\mathrm{e} 880 \mathrm{~nm}}\end{array}$} \\
\hline DLPI \# & Date & $\begin{array}{r}\text { Volume } \\
\left(\mathrm{m}^{3}\right)\end{array}$ & \multicolumn{2}{|c|}{ Size Cut $(\mu \mathrm{m})$} & $\mathrm{TC}$ & $\mathrm{EC}_{\mathrm{a}}$ & $\mathrm{EC}_{\mathrm{a}} / \mathrm{TC}$ & $\begin{array}{r}\mathrm{EC}_{\mathrm{a}} 572 \mathrm{~nm} \\
\text { (non-extracted) }\end{array}$ & $\begin{array}{r}\mathrm{EC}_{\mathrm{a}} 572 \mathrm{~nm} \\
\text { (non-extracted)/TC }\end{array}$ & $\begin{array}{l}\mathrm{EC}_{\mathrm{w} 572 \mathrm{~nm}} \\
\text { (extracted) }\end{array}$ & $\begin{array}{r}\mathrm{EC}_{\mathrm{w} 572 \mathrm{~nm}} \\
\text { (extracted)/TC }\end{array}$ & $\mathrm{BC}_{\mathrm{e} 880 \mathrm{~nm}}$ & $\mathrm{BC}_{\mathrm{e} 880 \mathrm{~nm}} / \mathrm{TC}$ & $\mathrm{OC}$ & \\
\hline \multirow[t]{15}{*}{3} & $17 \mathrm{Sep}$-night & 21.4 & 0.07 & 0.08 & 0.4 & 0.1 & 0.31 & NM & NM & NM & NM & 0.1 & 0.12 & 0.4 & \\
\hline & & & 0.08 & 0.10 & 0.6 & 0.2 & 0.36 & NM & NM & NM & NM & 0.1 & 0.12 & 0.5 & \\
\hline & & & 0.10 & 0.16 & 1.6 & 0.7 & 0.45 & NM & NM & NM & NM & 0.1 & 0.09 & 1.5 & \\
\hline & & & 0.16 & 0.27 & 4.8 & 2.1 & 0.44 & NM & NM & NM & NM & 0.3 & 0.07 & 4.4 & \\
\hline & & & 0.27 & 0.39 & 9.2 & 4.2 & 0.45 & NM & NM & NM & NM & 0.6 & 0.7 & 8.6 & \\
\hline & & & 0.39 & 0.62 & 19.5 & 9.9 & 0.51 & NM & NM & NM & NM & 1.0 & 0.05 & 18.5 & \\
\hline & & & 0.62 & 0.97 & 14.1 & 6.0 & 0.43 & NM & NM & NM & NM & 0.8 & 0.06 & 13.3 & \\
\hline & & & 0.97 & 1.6 & 8.8 & 3.2 & 0.36 & NM & NM & NM & NM & 0.8 & 0.09 & 8.0 & \\
\hline & & & 1.6 & 2.4 & 3.4 & 1.3 & 0.37 & NM & NM & NM & NM & 0.5 & 0.16 & 2.9 & \\
\hline & & & 2.4 & 4.1 & 2.7 & 0.8 & 0.31 & NM & NM & NM & NM & 0.3 & 0.13 & 2.4 & \\
\hline & & & 4.1 & 6.7 & 1.9 & 0.5 & 0.29 & NM & NM & NM & NM & 0.2 & 0.08 & 1.7 & \\
\hline & & & 6.7 & 10 & 1.0 & 0.3 & 0.32 & NM & NM & NM & NM & 0.2 & 0.22 & 0.8 & \\
\hline & & & 10 & 30 & 1.0 & 0.3 & 0.28 & NM & NM & NM & NM & 0.1 & 0.11 & 0.9 & \\
\hline & & & Fine & & 62.4 & 27.7 & 0.44 & NM & NM & NM & NM & 4.3 & 0.07 & 58.1 & $3.6 \pm 0.5$ \\
\hline & & & Coarse & & 6.5 & 2.0 & 0.31 & NM & NM & NM & NM & 0.8 & 0.12 & 5.7 & \\
\hline \multirow{15}{*}{11} & 26 Sep-day & 12.6 & 0.05 & 0.07 & 0.6 & 0.2 & 0.27 & 0.1 & 0.21 & 0.1 & 0.08 & 0.1 & 0.20 & 0.5 & \\
\hline & & & 0.07 & 0.10 & 0.8 & 0.3 & 0.35 & 0.2 & 0.24 & 0.0 & 0.02 & 0.0 & & 0.8 & \\
\hline & & & 0.10 & 0.16 & 2.7 & 1.0 & 0.37 & 0.5 & 0.17 & 0.3 & 0.09 & 0.1 & 0.05 & 2.5 & \\
\hline & & & 0.16 & 0.27 & 6.9 & 2.7 & 0.39 & 0.6 & 0.09 & 0.6 & 0.08 & 0.5 & 0.07 & 6.4 & \\
\hline & & & 0.27 & 0.39 & 12.6 & 4.7 & 0.37 & 1.3 & 0.11 & 0.6 & 0.05 & 0.6 & 0.05 & 11.9 & \\
\hline & & & 0.39 & 0.62 & 16.8 & 5.5 & 0.33 & 1.8 & 0.11 & 1.5 & 0.09 & 1.0 & 0.06 & 15.8 & \\
\hline & & & 0.62 & 0.97 & 9.8 & 3.5 & 0.36 & 1.2 & 0.12 & 0.9 & 0.09 & 0.7 & 0.07 & 9.1 & \\
\hline & & & 0.97 & 1.6 & 3.3 & 1.4 & 0.42 & 0.6 & 0.18 & 0.3 & 0.09 & 0.3 & 0.09 & 3.0 & \\
\hline & & & 1.6 & 2.4 & 1.5 & 0.6 & 0.40 & 0.4 & 0.27 & 0.1 & 0.05 & & & & \\
\hline & & & 2.4 & 4.1 & 1.0 & 0.3 & 0.27 & 0.3 & 0.28 & 0.0 & 0.03 & 0.1 & 0.10 & 0.9 & \\
\hline & & & 4.1 & 6.7 & 0.1 & 0.1 & 0.49 & & & 0.0 & 0.40 & 0.1 & 1.03 & 0.0 & \\
\hline & & & 6.7 & 10 & & 0.00 & & & & & & 0.0 & & 0.0 & \\
\hline & & & 10 & 30 & 0.7 & 0.3 & 0.51 & & & & & & & & \\
\hline & & & Fine & & 54.9 & 19.9 & 0.36 & 6.7 & 0.12 & 4.3 & 0.08 & 3.4 & 0.06 & 50 & $2 \pm 1$ \\
\hline & & & Coarse & & 1.7 & 0.7 & 0.41 & 0.3 & 0.18 & 0.1 & 0.06 & 0.2 & 0.12 & 0.9 & \\
\hline \multirow[t]{15}{*}{12} & 26 Sep-night & 21.2 & 0.05 & 0.07 & 0.2 & & 0.00 & NM & NM & NM & NM & 0.1 & 0.43 & 0.1 & \\
\hline & & & 0.07 & 0.10 & 0.2 & & 0.00 & NM & NM & NM & NM & 0.1 & 0.32 & 0.1 & \\
\hline & & & 0.10 & 0.16 & 0.9 & 0.4 & 0.48 & NM & NM & NM & NM & 0.1 & 0.13 & 0.7 & \\
\hline & & & 0.16 & 0.27 & 2.0 & 0.9 & 0.45 & NM & NM & NM & NM & 0.3 & 0.15 & 1.7 & \\
\hline & & & 0.27 & 0.39 & 4.5 & 1.8 & 0.41 & NM & NM & NM & NM & 0.4 & 0.10 & 4.0 & \\
\hline & & & 0.39 & 0.62 & 9.3 & 3.3 & 0.36 & NM & NM & NM & NM & 0.7 & 0.08 & 8.6 & \\
\hline & & & 0.62 & 0.96 & 7.8 & 2.6 & 0.34 & NM & NM & NM & NM & 0.8 & 0.10 & 7.0 & \\
\hline & & & 0.96 & 1.6 & 3.6 & 1.3 & 0.36 & NM & NM & NM & NM & 0.6 & 0.16 & 3.0 & \\
\hline & & & 1.6 & 2.4 & 1.1 & 0.6 & 0.49 & NM & NM & NM & NM & 0.3 & 0.23 & 0.9 & \\
\hline & & & 2.4 & 4.1 & 1.1 & 0.4 & 0.36 & NM & NM & NM & NM & 0.5 & 0.45 & 0.6 & \\
\hline & & & 4.1 & 6.7 & 0.6 & 0.2 & 0.34 & NM & NM & NM & NM & 0.2 & 0.33 & 0.4 & \\
\hline & & & 6.7 & 10 & 0.3 & 0.1 & 0.44 & NM & NM & NM & NM & 0.1 & 0.37 & 0.2 & \\
\hline & & & 10 & 30 & 0.2 & 0.1 & 0.47 & NM & NM & NM & NM & 0.1 & 0.30 & 0.2 & \\
\hline & & & Fine & & 30 & 11 & 0.37 & NM & NM & NM & NM & 3.3 & 0.11 & 26 & $1.9 \pm 0.4$ \\
\hline & & & Coarse & & 2 & 0.9 & 0.45 & NM & NM & NM & NM & 0.9 & 0.45 & 14 & \\
\hline \multirow[t]{15}{*}{13} & 27 Sep-day & 13.4 & 0.05 & 0.06 & 0.6 & 0.2 & 0.28 & & 0.00 & & 0.00 & 0.0 & 0.02 & 0.6 & \\
\hline & & & 0.06 & 0.10 & 0.5 & 0.2 & 0.28 & & 0.00 & & 0.00 & 0.0 & 0.08 & 0.5 & \\
\hline & & & 0.10 & 0.16 & 1.2 & 0.4 & 0.36 & 0.43 & 0.37 & 0.2 & 0.14 & 0.1 & 0.10 & 1.1 & \\
\hline & & & 0.16 & 0.27 & 2.8 & 1.2 & 0.44 & 1.19 & 0.43 & 0.4 & 0.15 & 0.2 & 0.09 & 2.5 & \\
\hline & & & 0.27 & 0.39 & 5.3 & 2.1 & 0.39 & 0.73 & 0.14 & 0.6 & 0.11 & 0.3 & 0.06 & 5.0 & \\
\hline & & & 0.39 & 0.62 & 7.1 & 2.3 & 0.32 & 0.61 & 0.09 & 0.39 & 0.05 & 0.8 & 0.11 & 6.3 & \\
\hline & & & 0.62 & 0.96 & 4.1 & 1.3 & 0.31 & 0.63 & 0.15 & 0.2 & 0.06 & 0.4 & 0.10 & 3.7 & \\
\hline & & & 0.96 & 1.6 & 1.7 & 0.8 & 0.44 & 0.44 & 0.26 & & & 0.2 & 0.12 & 1.5 & \\
\hline & & & 1.6 & 2.4 & 0.6 & 0.3 & 0.47 & 0.18 & 0.29 & 0.1 & 0.13 & 0.1 & 0.09 & 0.6 & \\
\hline & & & 2.4 & 4.1 & 0.9 & 0.3 & 0.28 & 0.33 & 0.37 & 0.04 & 0.04 & & & 0.9 & \\
\hline & & & 4.1 & 6.7 & 0.8 & 0.3 & 0.32 & 0.12 & 0.16 & 0.05 & 0.07 & 0.0 & 0.06 & 0.7 & \\
\hline & & & 6.7 & 10 & 0.2 & 0.08 & 0.35 & 0.02 & 0.08 & & 0.00 & & & 0.2 & \\
\hline & & & 10 & 30 & 0.3 & 0.09 & 0.31 & & 0.00 & & 0.00 & & & 0.3 & \\
\hline & & & Fine & & 24 & 8.6 & 0.36 & 4.21 & 0.18 & 1.83 & 0.08 & 2.20 & 0.09 & 22 & $1.1 \pm 0.3$ \\
\hline & & & Coarse & & 2 & 0.7 & 0.35 & 0.47 & 0.24 & 0.09 & 0.05 & 0.00 & 0.00 & 2 & \\
\hline
\end{tabular}

of water-soluble organic compounds and/or mechanical dislodging of insoluble $\mathrm{EC}_{\mathrm{a}}$. Water extraction resulted in a shift in the evolution of the most refractory material to higher temperatures (the last peak appeared at $\sim 450^{\circ} \mathrm{C}$ before water extraction and at $\sim 520^{\circ} \mathrm{C}$ after water extraction), most likely because of the removal of water-soluble ions such as $\mathrm{K}^{+}$and
$\mathrm{Na}^{+}$that catalyze the combustion of $\mathrm{EC}_{\mathrm{a}}$ (Novakov and Corrigan, 1995; Mayol-Bracero et al., 2002a).

Changes in embedded soot morphology may also have played a role in altering the optical properties of material in the filter after the extraction with water. Also, after extraction with water; the single peak above $450^{\circ}$ split into two peaks, 
Table 1. Continued.

\begin{tabular}{|c|c|c|c|c|c|c|c|c|c|c|c|c|c|c|c|}
\hline \multicolumn{5}{|c|}{$\begin{array}{l}\text { Method } \\
\text { used } \Longrightarrow\end{array}$} & \multicolumn{7}{|c|}{ EGA* $^{*}$} & \multicolumn{3}{|c|}{ LTM $^{* *}$} & \multirow{2}{*}{$\begin{array}{l}\text { Aethalometer } \\
\mathrm{BC}_{\mathrm{e} 880 \mathrm{~nm}}\end{array}$} \\
\hline DLPI \# & Date & $\begin{array}{r}\text { Volume } \\
\left(\mathrm{m}^{3}\right)\end{array}$ & Size Cu & $(\mu \mathrm{m})$ & $\mathrm{TC}$ & $\mathrm{EC}_{\mathrm{a}}$ & $\mathrm{EC}_{\mathrm{a}} / \mathrm{TC}$ & $\begin{array}{r}\mathrm{EC}_{\mathrm{a}} 572 \mathrm{~nm} \\
\text { (non-extracted) }\end{array}$ & $\begin{array}{r}\mathrm{EC}_{\mathrm{a}} 572 \mathrm{~nm} \\
\text { (non-extracted)/TC }\end{array}$ & $\begin{array}{l}\mathrm{EC}_{\mathrm{w} 572 \mathrm{~nm}} \\
\text { (extracted) }\end{array}$ & $\begin{array}{r}\mathrm{EC}_{\mathrm{w} 572 \mathrm{~nm}} \\
\text { (extracted)/TC }\end{array}$ & $\mathrm{BC}_{\mathrm{e} 880 \mathrm{~nm}}$ & $\mathrm{BC}_{\mathrm{e} 880 \mathrm{~nm}} / \mathrm{TC}$ & $\mathrm{OC}$ & \\
\hline \multirow[t]{15}{*}{15} & 28 Sep-day & 14.7 & 0.05 & 0.06 & & & & & & & & NM & NM & & \\
\hline & & & 0.06 & 0.10 & 0.7 & 0.2 & 0.27 & 0.14 & 0.21 & & & NM & NM & & \\
\hline & & & 0.10 & 0.16 & 1.4 & 0.5 & 0.35 & 0.34 & 0.25 & 0.1 & 0.09 & NM & NM & & \\
\hline & & & 0.16 & 0.27 & 3.1 & 1.3 & 0.41 & 0.81 & 0.26 & 0.4 & 0.12 & NM & NM & & \\
\hline & & & 0.27 & 0.39 & 6.4 & 2.5 & 0.40 & 0.41 & 0.06 & 0.9 & 0.15 & NM & NM & & \\
\hline & & & 0.39 & 0.62 & 9.5 & 3.5 & 0.36 & 1.43 & 0.15 & 1.0 & 0.10 & NM & NM & & \\
\hline & & & 0.62 & 0.96 & 6.1 & 2.3 & 0.38 & 0.84 & 0.14 & 0.6 & 0.10 & NM & NM & & \\
\hline & & & 0.96 & 1.6 & 1.8 & 0.8 & 0.43 & 0.47 & 0.26 & 0.3 & 0.16 & NM & NM & & \\
\hline & & & 1.6 & 2.4 & 1.2 & 0.5 & 0.40 & 0.39 & 0.33 & 0.1 & 0.08 & NM & NM & & \\
\hline & & & 2.4 & 4.1 & 1.2 & 0.4 & 0.31 & 0.24 & 0.21 & & & NM & NM & & \\
\hline & & & 4.1 & 6.7 & 0.7 & 0.2 & 0.30 & 0.18 & 0.27 & & & NM & NM & & \\
\hline & & & 6.7 & 10 & 0.4 & 0.1 & 0.33 & & & & & NM & NM & & \\
\hline & & & 10 & 30 & 0.4 & 0.1 & 0.32 & & & & & NM & NM & & \\
\hline & & & Fine & & 30 & 11.5 & 0.38 & 4.83 & 0.161 & 3.4 & 0.11 & & & & $1.0 \pm 0.4$ \\
\hline & & & Coarse & & 3 & 0.8 & 0.27 & 0.42 & 0.14 & 0 & 0 & & & & \\
\hline \multirow[t]{19}{*}{25} & 4 Oct-night & 22.0 & 0.05 & 0.06 & 0.3 & 0.1 & 0.42 & NM & NM & NM & NM & 0.2 & 0.55 & 0.2 & \\
\hline & & & 0.06 & 0.10 & 0.6 & 0.2 & 0.40 & NM & NM & NM & NM & 0.1 & 0.17 & 0.5 & \\
\hline & & & 0.10 & 0.16 & 1.8 & 0.8 & 0.45 & NM & NM & NM & NM & 0.1 & 0.08 & 1.6 & \\
\hline & & & 0.16 & 0.27 & 4.4 & 2.1 & 0.47 & NM & NM & NM & NM & 0.2 & 0.06 & 4.1 & \\
\hline & & & 0.27 & 0.39 & 11.1 & 5.3 & 0.48 & NM & NM & NM & NM & 0.3 & 0.03 & 10.8 & \\
\hline & & & 0.39 & 0.62 & 22.8 & 11.1 & 0.49 & NM & NM & NM & NM & 1.2 & 0.05 & 21.6 & \\
\hline & & & 0.62 & 0.96 & 15.9 & 7.0 & 0.44 & NM & NM & NM & NM & 1.1 & 0.07 & 14.8 & \\
\hline & & & 0.96 & 1.6 & 6.4 & 2.5 & 0.38 & NM & NM & NM & NM & 0.7 & 0.10 & 5.8 & \\
\hline & & & 1.6 & 2.4 & 1.3 & 0.6 & 0.47 & NM & NM & NM & NM & 0.6 & 0.51 & 0.6 & \\
\hline & & & 2.4 & 4.1 & 2.2 & 0.7 & 0.32 & NM & NM & NM & NM & 0.5 & 0.21 & 1.8 & \\
\hline & & & 4.1 & 6.7 & 1.7 & 0.6 & 0.32 & NM & NM & NM & NM & 0.0 & 0.00 & 1.7 & \\
\hline & & & 6.7 & 10 & 0.8 & 0.3 & 0.37 & NM & NM & NM & NM & 0.2 & 0.23 & 0.6 & \\
\hline & & & 10 & 30 & 0.3 & 0.1 & 0.51 & NM & NM & NM & NM & 0.2 & 0.64 & 0.1 & \\
\hline & & & Fine & & 65 & 29 & 0.45 & & & & & 4.5 & 0.07 & 60 & $3.4 \pm 0.8$ \\
\hline & & & Coarse & & 5 & 2 & 0.4 & & & & & 0.8 & 0.16 & 4.2 & \\
\hline & & & & & 44 & 18 & 0.37 & 5 & 0.15 & 3 & 0.09 & 3.6 & 0.08 & 43 & 2.2 \\
\hline & Average & & Fine & & 18 & 9 & 0.01 & 1 & 0.03 & 1 & 0.02 & 0.9 & 0.02 & 18 & 0.6 \\
\hline & & & & & 3 & 1.1 & 0.34 & 0.4 & 0.18 & 0.05 & 0.03 & 0.6 & 0.2 & 3 & NM \\
\hline & STDEV & & Coarse & & 2 & 0.6 & 0.07 & 0.1 & 0.05 & 0.05 & 0.03 & 0.4 & 0.2 & 2 & \\
\hline
\end{tabular}

at $\sim 470^{\circ} \mathrm{C}$ and $520^{\circ} \mathrm{C}$. This was observed for all samples with $D_{p}<1.6 \mu \mathrm{m}$. These two peaks have not been reported before and might have been due to different classes of highly refractory carbonaceous material.

Optical characterization during thermal analysis was also used to determine EC concentrations more accurately. Figure 3 shows light attenuation (at $572 \mathrm{~nm}$ ) by sample DLPI\#11-stage 4 (nominal $D_{p}$ from $0.2-0.3 \mu \mathrm{m}$ ) throughout the thermal analysis, before $\left(\mathrm{EC}_{\mathrm{a} 572 \mathrm{~nm}}\right)$ and after the water extraction $\left(\mathrm{EC}_{\mathrm{w} 572 \mathrm{~nm}}\right)$. The point of zero attenuation was used to define the split between $\mathrm{OC}$ and $\mathrm{EC}_{\mathrm{a} 572 \mathrm{~nm}}$ and/or $\mathrm{EC}_{\mathrm{w} 572 \mathrm{~nm}}$. The formation of char from OC pyrolyzed in the un-extracted sample is evident from the increased attenuation. Relatively little charring was observed in the water extracted sample. Thus, the water-soluble material, which can be removed by the extraction technique, was responsible for most of the charring. Concentrations of $\mathrm{EC}_{\mathrm{a} 572 \mathrm{~nm}}$ and $\mathrm{EC}_{\mathrm{w} 572 \mathrm{~nm}}$ were averaged for three samples, and were $5 \pm 1$ and $3 \pm 1 \mu \mathrm{g} \mathrm{m}^{-3}$, respectively. $\mathrm{BC}_{\mathrm{e}}$ concentrations $\left(D_{p}<2.5 \mu \mathrm{m}\right)\left(\mathrm{BC}_{\mathrm{e} 880 \mathrm{~nm}}\right)$ were estimated using LTM only (i.e., not in combination with thermal analysis, at $\sigma$ (specific attenuation $\left.)=16.6 \mathrm{~m}^{2} \mathrm{~g}^{-1}\right)$ and were $3.6( \pm 0.9) \mu \mathrm{g} \mathrm{m}^{-3}$.

\subsubsection{Estimating the positive artifact}

The determination of the sampling artifacts (postive and negative), related to the adsorption of volatile organic compounds (VOCs) and the adsorption or losses of semi-volatile organic compounds (SVOC), is important to obtain reliable concentrations of the carbonaceous aerosol fraction. As explained in Sect. 2.1.1, positive artifacts were estimated by comparing TC measurements from the DLPI with those from several other systems (R2.5WW, Carbon Monitor, and HVDS) used in this study (see also Table 2).

TC concentrations collected on all DLPI stages with $D_{p}<2.5 \mu \mathrm{m}$ were summed in order to compare with the bulk filter systems (Fig. 4a). The regression for the entire dry season between the DLPI and the R2.5WW systems was: $\mathrm{TC}_{(\mathrm{DLPI})}=1.06 * \mathrm{TC}{ }_{(\mathrm{R} 2.5 \mathrm{WW})}+4.4, r^{2}=0.89 ; n=8$ (concentrations in $\mu \mathrm{g} \mathrm{m}^{-3}$; standard error of the slope: \pm 0.36 ). This result indicates an overestimation for the impactor sampling (using only quartz fiber filters as substrates) that could be attributed to the positive artifact of VOCs and SVOCs. In comparison, the positive artifact averaged for the HVDS (UGent) was $5.2 \%$ (back filter to front filter OC concentration ratio of $0.052 \pm 0.055$ ).

TC concentrations for the DLPI were higher than for the other samplers for the majority of day time samples (Fig. 4b and Table 2). A DLPI system with quartz fiber filters may 
Table 2. TC concentration results from the DLPI and different filter systems. These samples were collected during the dry period of the LBA-SMOCC-2002 campaign. All concentrations are given in $\mu \mathrm{g} \mathrm{m}^{-3}$. STDEV refers to the standard deviation of the average.

\begin{tabular}{lrrrrrr}
\hline Sample $^{\mathrm{a}}$ & $\begin{array}{r}\text { DLPI } \\
\text { (UPR) }\end{array}$ & $\begin{array}{r}\text { R2.5WW } \\
\text { (UGent) }\end{array}$ & $\begin{array}{r}\text { Carbon Monitor } \\
\text { (USP) }\end{array}$ & $\begin{array}{r}\text { HVDS } \\
\text { (MPIC) }\end{array}$ & $\begin{array}{r}\text { 1HVDS } \\
\text { (UGent) }\end{array}$ & $\begin{array}{r}\text { 2HVDS } \\
\text { (UGent) }\end{array}$ \\
\hline 15 Sep N & 17.4 & 16.6 & 14.8 & 14.1 & 16.7 & 15.9 \\
16 Sep N & 53.9 & 51.2 & 48.4 & 44.1 & 52.3 & 49.0 \\
17 Sep N & 67.0 & 51.9 & 64.6 & 30.7 & 57.7 & 51.1 \\
23 Sep N & 29.9 & 29.6 & 34.8 & 34.2 & 36.2 & 34.4 \\
24 Sep D & 16.1 & 22.6 & 21.9 & 20.9 & 20.8 & 21.1 \\
25 Sep D & 81.2 & 64.0 & 57.2 & - & 69.7 & 64.0 \\
26 Sep D & 50.0 & 33.9 & 34.1 & 32.0 & 31.2 & 32.5 \\
27 Sep D & 27.6 & 16.4 & 15.7 & 14.8 & 17.9 & 15.7 \\
29 Sep & 7.4 & 8.0 & 6.4 & 6.7 & 7.8 & 7.0 \\
30 Sep & 13.2 & 9.3 & 7.2 & 8.9 & 9.8 & 8.8 \\
3 Oct D & 15.6 & 17.3 & 22.9 & 16.4 & 18.7 & 16.9 \\
3 Oct N & 57.9 & 47.9 & 58.0 & 51.8 & 57.6 & 50.1 \\
4 Oct D & 30.9 & 27.5 & 24.2 & 24.7 & 28.8 & 26.8 \\
4 Oct N & 58.4 & 50.1 & 60.7 & 51.8 & 60.7 & 54.4 \\
6 Oct D & 30.9 & 23.6 & 24.7 & - & 24.7 & 22.2 \\
7 Oct N & 27.9 & 26.5 & 27.2 & - & 27.4 & 24.4 \\
\hline Day Average & 36 & 29 & 29 & 22 & 30 & 28 \\
STDEV & 23 & 16. & 14 & 7 & 18 & 17 \\
\hline Night Average & 44 & 39 & 44 & 38 & 44 & 40 \\
STDEV $^{\text {b }}$ & 19 & 15 & 19 & 15 & 17 & 15 \\
\hline
\end{tabular}

${ }^{\text {a }}$ The samples collected between 15 Sep-27 Sep and 3 Oct-7 Oct are from 12-h periods; the date indicates the starting date of sampling, D and N represent day and night samples, respectively. The samples from $29-30$ Sep were collected over $24-\mathrm{h}$ periods. ${ }^{\mathrm{b}}$ The samples used, from the DLPI, to obtain the contribution of the carbonaceous material to the total aerosol mass in Section 3.3; $\left(33.6 \pm 31.7 \mu \mathrm{g} \mathrm{m}^{-3}\right)$.

overestimate $\mathrm{OC}$ between $\sim 15 \%$ (night time) and $\sim 30 \%$ (day time) due to absorption of the SVOCs emitted during biomass burning. This behavior is expected, since there are at least as much volatile organic gases as aerosols emitted during biomass combustion (Robinson et al., 2007), and these gases might be collected by filter samplers, especially when using quartz fiber filters. Differences between day and night can also be explained because the gas-particle equilibrium moves towards the gas phase during the day due to the higher temperatures (Trebs et al., 2005).

In addition, it is important to state that some of the carbonaceous material observed in the DLPI might come also from a redistribution of semi-volatile organic species across different filter/impactor stages (negative artifact), and not only from the adsorption of gases (positive artifact). Also, the differences ( 3 to 6 times higher) found between the positive artifacts in the HVDS and the DLPI might have been due to accuracy of the volume measurement in the DLPI, the higher losses of organic compounds from the upper stages (coarse particles) to the lower ones (fine particles) in the DLPI due to the low pressure (much lower than the HVDS) it uses and, also a small contribution from the high face velocity in the impactors.

\subsubsection{Estimating the EC and BC concentrations}

A problem for the determination of $\mathrm{EC}_{\mathrm{a}}$ or $\mathrm{BC}_{\mathrm{e}}$ on cascade impactor samples is the fact that deposits are usually not uniform on the sampling substrates. In Fig. 5 we compare the $\mathrm{EC}\left(\mathrm{EC}_{\mathrm{a}}\right.$ and $\left.\mathrm{EC}_{\mathrm{w}}\right)$ and $\mathrm{BC}_{\mathrm{e}}$ concentrations measured by different methods and techniques. The carbon monitor usually had concentrations more than three times higher than the other systems. With this system, $\mathrm{EC}_{\mathrm{a}}$ was defined as the carbon content oxidized above $350{ }^{\circ} \mathrm{C}$ (Artaxo et al., 2002), and most likely included significant amounts of OC.

The $\mathrm{EC}_{\mathrm{a}}$ measured with the thermal optical transmittance (TOT) system for both HVDS samplers from UGent was more than three times lower than the $\mathrm{EC}_{\mathrm{W}}$ for all the other systems. These TOT measurements are so much lower than those from all other techniques because the temperature program used in the TOT analysis (NIOSH standard temperature program) (Schmid et al., 2001) can affect the definition of the $\mathrm{OC}$ and $\mathrm{EC}_{\mathrm{a}}$ split (Sciare et al., 2008; Chow et al., 2001, 2004; Schmid et al., 2001; Birch and Cary, 1996; NIOSH, 1996, 1999). Some additional insight comes from a comparison of the TOT(UGent) measurements with analyses of an additional sample set from SMOCC-2002, where the TOT technique was used in parallel with the IM- 
Table 3. Comparison of $\mathrm{TC}$ and $\mathrm{EC}_{\mathrm{a}}$ measurements by two different laboratories (University of Gent (Gent) and Desert Research Institute (DRI)) using the TOT and TOR techniques. All concentrations are given in $\mu \mathrm{g} \mathrm{m}^{-3}$.

\begin{tabular}{|c|c|c|c|c|c|c|c|}
\hline Sample ${ }^{\mathrm{a}}$ & $\begin{array}{r}\text { TC } \\
\text { DRI }\end{array}$ & Gent & $\mathrm{EC}_{\mathrm{a}}(\mathrm{TOR})$ & $\begin{array}{r}\mathrm{EC}_{\mathrm{a}}(\mathrm{TOT}) \\
\text { DRI }\end{array}$ & $\begin{array}{r}\mathrm{EC}_{\mathrm{a}}(\mathrm{TOT}) \\
\text { Gent }\end{array}$ & $\begin{array}{r}\mathrm{EC}_{\mathrm{a}} \text { Ratio } \\
\mathrm{TOR}_{\mathrm{DRI}} / \\
\text { TOT }_{\text {DRI }}\end{array}$ & $\begin{array}{c}\mathrm{EC}_{\mathrm{a}} \text { Ratio } \\
\text { TOR }_{\mathrm{DRI}} / \\
\text { TOT }_{\text {Gent }}\end{array}$ \\
\hline 18 Sep D & 21.4 & 28.1 & 3.2 & 1.8 & 0.8 & 1.8 & 4.0 \\
\hline 18 Sep N & 58.3 & 54.2 & 5.7 & 3.1 & 2.1 & 1.8 & 2.7 \\
\hline 19 Sep D & 27.4 & 40.0 & 2.6 & 0.2 & 0.8 & 17.1 & 3.5 \\
\hline 19 Sep N & 74.7 & 78.5 & 9.6 & 5.6 & 2.2 & 1.7 & 4.4 \\
\hline 20 Sep N & 76.1 & 84.1 & 6.2 & 0.3 & 2.0 & 19.4 & 3.1 \\
\hline 13 Oct D & 8.6 & 12.1 & 1.4 & 0.7 & 0.4 & 1.9 & 3.8 \\
\hline 13 Oct $\mathrm{N}$ & 12.4 & 13.4 & 2.4 & 1.3 & 0.7 & 1.9 & 3.6 \\
\hline $16 \mathrm{Oct}$ & 7.2 & 7.4 & 1.3 & 0.7 & 0.4 & 2.0 & 3.7 \\
\hline 17 Oct & 13.4 & 13.6 & 2.2 & 1.1 & 0.5 & 2.0 & 4.5 \\
\hline 18 Oct & 13.3 & 14.1 & 2.1 & 1.0 & 0.6 & 2.2 & 3.7 \\
\hline Average & 31 & 35 & 4 & 2 & 1.0 & 2 & 3.7 \\
\hline STDEV & 30 & 30 & 3 & 2 & 0.8 & 7 & 0.5 \\
\hline
\end{tabular}

a The samples collected between 18 Sep and 13 Oct are for 12-h periods; the date indicates the starting date of sampling, D and $\mathrm{N}$ represent day and night samples, respectively. The samples from 16-18 Oct were collected over 24-h periods.

PROVE thermal-optical reflectance (TOR) technique (Chow et al., 2004). The data in Table 3 show that for the TC measurements, which are identical for the TOR (DRI) and TOT (UGent) techniques, there was good agreement between the two laboratories. However, the $\mathrm{EC}_{\mathrm{a}}$ measurements by TOR are always much higher than those by TOT. This also applies to the TOT and TOR results by the Desert Research Institute (DRI) lab, where the TOR values are about a factor of two higher than the TOT values (excluding two outliers), even though they were obtained in the same runs and with the same temperature programs. The differences between the TOR and TOT results have been attributed to charring within the filter matrix, which leads to correction artifacts in TOT, but not in TOR (Chow et al., 2004). The even larger difference between the TOT $\mathrm{EC}_{\mathrm{a}}$ values by UGent and the TOR measurements by DRI, which were on average 3.7 times higher, probably results from the use of a different instrument, different temperature calibration methods (Chow et al., 2005), and different temperature programs in addition to the TOR/TOT differences. Unfortunately, the sample set analyzed at DRI did not overlap with the impactor sampling periods, making a direct comparison impossible.

Results from the aethalometer after correcting for the filter loading and multiple scattering for $\mathrm{BC}_{\mathrm{e}}$ at $880 \mathrm{~nm}$ were $\sim 40 \%$ lower than the values reported from the aethalometer without corrections (average of $1.9 \pm 1.0 \mu \mathrm{g} \mathrm{m}^{-3}$ with corrections, compared to $3.3 \pm 1.7 \mu \mathrm{g} \mathrm{m}^{-3}$ without). The $\mathrm{BC}_{\mathrm{e}}$ concentrations obtained by summing the values obtained on the DLPI stages with the LTM (average $3.6 \pm 0.9 \mu \mathrm{g} \mathrm{m}^{-3}$ ) were comparable to the uncorrected $\mathrm{BC}_{\mathrm{e}}$ concentrations measured with the aethalometer. Correction factors analo- gous to the Weingartner corrections for the aethalometer are not available for the LTM, unfortunately.

The $\mathrm{EC}_{\mathrm{w}}$ HVDS (MPIC) measured using the EGA, after extraction with water, shows a high standard deviation which does not allow comparison with the other systems. Results from the LTM, TOR and TOA (after extracting with water and correcting for charring using $572 \mathrm{~nm}$ ) were similar for $\mathrm{BC}_{\mathrm{e}}$ and $\mathrm{EC}_{\mathrm{w}}$.

To help determine the source of the $\mathrm{EC}_{\mathrm{a}}$ and $\mathrm{BC}_{\mathrm{e}}$, we plotted their concentrations as a function of TC concentrations for the fine fraction (sum of impactor stages with nominal $\left.D_{p}<2.5 \mu \mathrm{m}\right)$. Figure $6 \mathrm{a}$ and $\mathrm{b}$ show a good correlation of $\mathrm{EC}_{\mathrm{a}}, \mathrm{EC}_{\mathrm{a} 572 \mathrm{~nm}}, \mathrm{EC}_{\mathrm{w} 572 \mathrm{~nm}}$ and $\mathrm{BC}_{\mathrm{e}}$ with TC $\left(r^{2} \sim 0.96,0.99\right.$, 0.75 and 0.81 , respectively), suggesting that carbonaceous aerosols were from biomass burning. Also, the strong correlation $\left(r^{2} \sim 0.99\right)$ of $\mathrm{BC}_{\mathrm{e}}$ with potassium, a tracer of biomass burning (Andreae et al., 1983), makes it clear that biomass burning is the dominant aerosol source. This was expected for the dry season since there were many fires in the region (Fuzzi et al., 2007). The $\mathrm{EC}_{\mathrm{a}}, \mathrm{EC}_{\mathrm{w}}$, and $\mathrm{BC}_{\mathrm{e}} / \mathrm{TC}$ mass ratios per stage for each sample are given in Table 1.

The $\mathrm{EC}_{\mathrm{a}} / \mathrm{TC}$ slope in Fig. 6a shows an unrealistically high value of 0.51 . This ratio is much higher than what has been previously reported for biomass burning samples in the same location (Mayol-Bracero et al., 2002a), and suggests that $\mathrm{EC}_{\mathrm{a}}$ was strongly overestimated due to the presence of a large amount of refractory water-soluble material or OC char (Mayol-Bracero et al., 2002a; Hadley et al., 2008). Our results in Fig. 6a and b for $\mathrm{EC}_{\mathrm{a} 572 \mathrm{~nm}} / \mathrm{TC}, \mathrm{EC}_{\mathrm{w} 572 \mathrm{~nm}} / \mathrm{TC}$, and $\mathrm{BC}_{\mathrm{e}} / \mathrm{TC}$ are $0.08,0.07$, and 0.04 , respectively. These values are similar to those from a TOT method at the same site: 

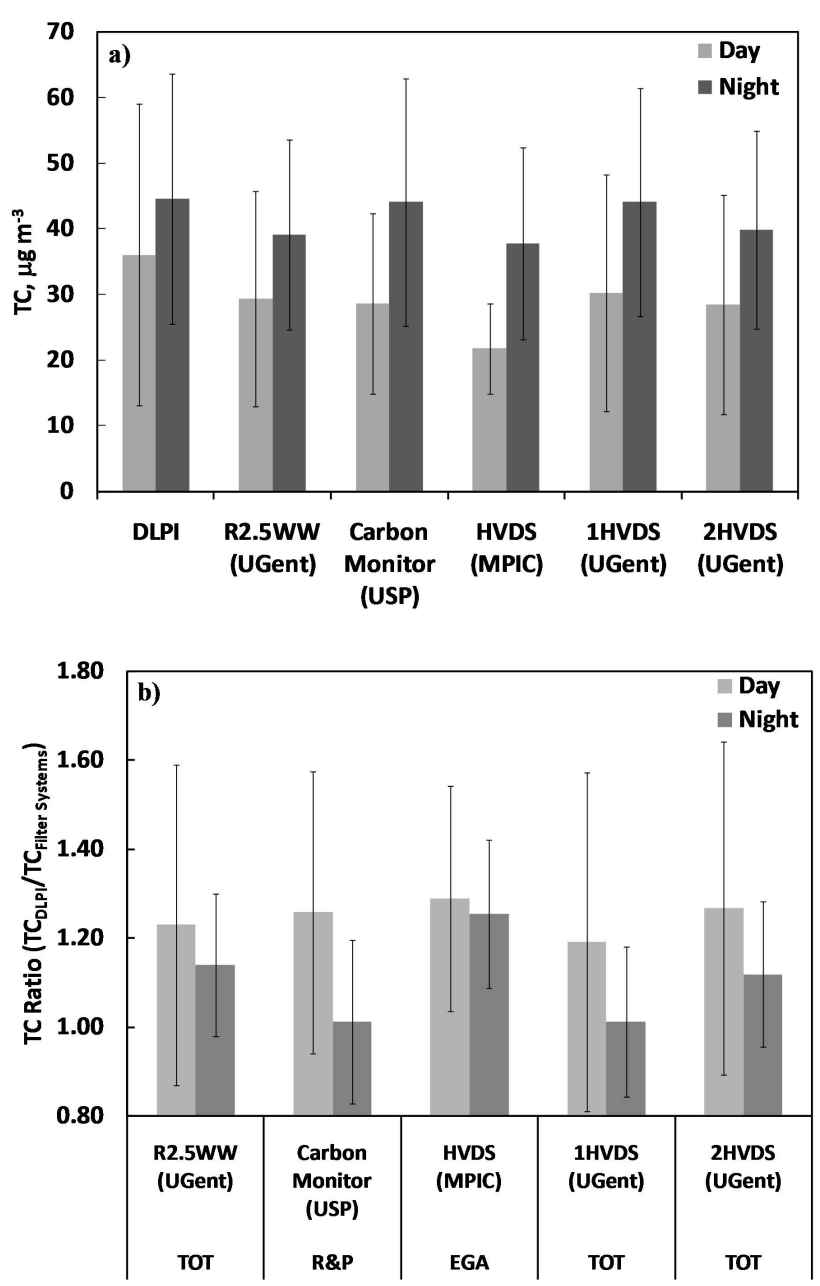

Fig. 4. (a) TC concentration averages $\left(D_{p}<2.5 \mu \mathrm{m}\right)$ for DLPI (UPR) and R2.5WW (UGent), carbon monitor (USP), HVDS (MPIC), 1HVDS (UGent), 2HVDS (UGent)) together with the standard deviation bars for day and night time samples. The number of samples used for each system were: DLPI (UPR) $-n=3$; R2.5WW (UGent), carbon monitor (USP), HVDS (MPIC), 1HVDS (UGent), 2 HVDS (UGent) $)-n=37$. (b) TC concentration ratio of the different filter systems relative to the DLPI $\left(D_{p}<2.5 \mu \mathrm{m}\right)$ for day and night time. The error bars presented here were calculated by using the error propagation rules.

0.05 (Guyon et al., 2003); a two-step thermal analysis from Brazilian cerrado, grass, and forest fires: 0.08 (smoldering) (Ferek et al., 1998), and the values mentioned in the review by Reid et al. (2005), showing that smoke particles were 5$10 \%$ BC by mass. Decesari et al. (2006) reported $\mathrm{EC}_{\mathrm{w}}$ values of 7-19\% of TC for the dry season during the SMOCC-2002 campaign. On the other hand, our $\mathrm{EC}_{\mathrm{w}}$ were about three times higher than those measured by the UGent TOT analysis, suggesting that the latter represent an underestimation due to the use of the NIOSH protocol by the Gent group. Our values from the TOA and LTM methods indicated that $4-8 \%$

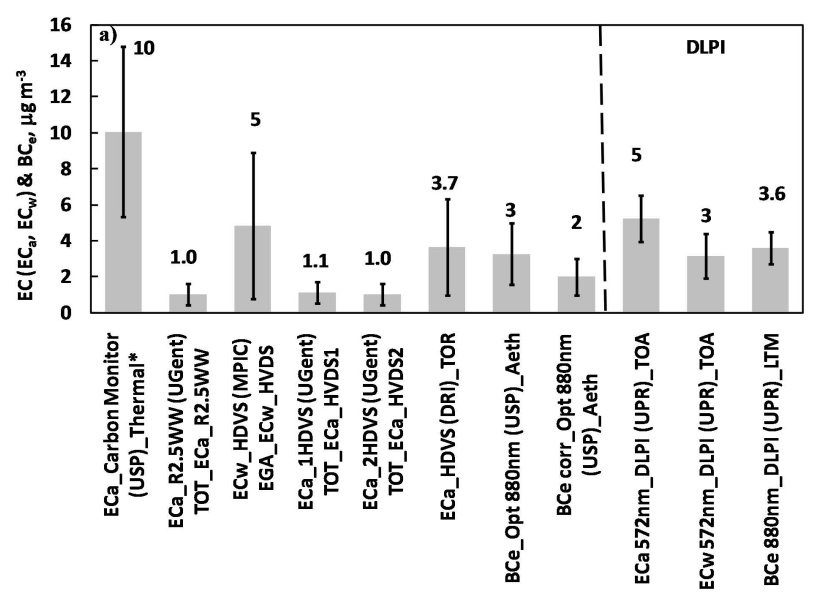

Fig. 5. (a) Comparison of $\mathrm{EC}\left(\mathrm{EC}_{\mathrm{a}}\right.$ and $\left.\mathrm{EC}_{\mathrm{W}}\right)$ and $\mathrm{BC}_{\mathrm{e}}$ averages for $D_{p}<2.5 \mu \mathrm{m}$ using the carbon monitor, HVDS (MIPC), 1HVDS (UGent), 2HVDS (UGent), Aethalometer (at $880 \mathrm{~nm}$ ), and the DLPI together with the standard deviation bars. Only for the aethalometer is $D_{p}<10 \mu \mathrm{m}$. EC $\mathrm{EC}_{\mathrm{a}}$ refers to non-extracted thermal samples and $\mathrm{EC}_{\mathrm{W}}$ refers to water extracted samples using thermal, TOA, and TOT methods. $\mathrm{BC}_{\mathrm{e}-\mathrm{Opt}} 880 \mathrm{~nm}$ refers to the species measured by the aethalometer at $880 \mathrm{~nm}$, and $\mathrm{BC}_{\mathrm{e}}$ corr Opt $880 \mathrm{~nm}$ refers to the species measured by the aethalometer at $880 \mathrm{~nm}$ and corrected for filter loading and multiple scattering (Weingartner et al., 2003; Schmid et al., 2006). BC 880 nm_DLPI refers to the species measured by the light transmission method at $880 \mathrm{~nm}$ and determined using a $\sigma=16.6 \mathrm{~m}^{2} \mathrm{~g}^{-1}$.

of the total carbon was $\mathrm{EC}_{\mathrm{a}}\left(\mathrm{BC}_{\mathrm{e}}\right)$. These results indicated that smoke particles were originating more from the smoldering phase of forest fires, as previously suggested by MayolBracero et al. (2002a) and Reid et al. (2005). Also, the addition of secondary organic aerosol could have led to lower $\mathrm{EC}_{\mathrm{a}} / \mathrm{TC}$ ratios and masked the nature of the fires responsible for the $\mathrm{EC}_{\mathrm{a}}$ emissions. However, aircraft and groundbased measurements of CO-to- $\mathrm{CO}_{2}$ emission ratios during SMOCC-2002 and other campaigns have shown that smoldering combustion, which releases aerosols with low $\mathrm{EC}_{\mathrm{a}} / \mathrm{TC}$ ratios, makes a large contribution to the emissions from deforestation fires, especially when sampled at ground level (Guyon et al., 2005; Yokelson et al., 2008).

In summary, our results show that all the methods used during SMOCC-2002 obtained reasonably comparable values for TC, with a modest overestimation in the impactor samples, probably due to the adsorption of organic vapors (positive artifact). Large discrepancies were found between the various techniques used to determine $\mathrm{EC}_{\mathrm{a}}$ and $\mathrm{BC}_{\mathrm{e}}$. In particular, the semi-continuous R\&P Carbon Monitor showed excessively high values, probably due to a low OC/EC cutoff temperature that led to the inclusion of a significant amount of $\mathrm{OC}$ in the $\mathrm{EC}_{\mathrm{a}}$ fraction. The $\mathrm{EC}_{\mathrm{a}}$ analysis of the impactor samples without water extraction or optical correction also gave unrealistically high values. On the 

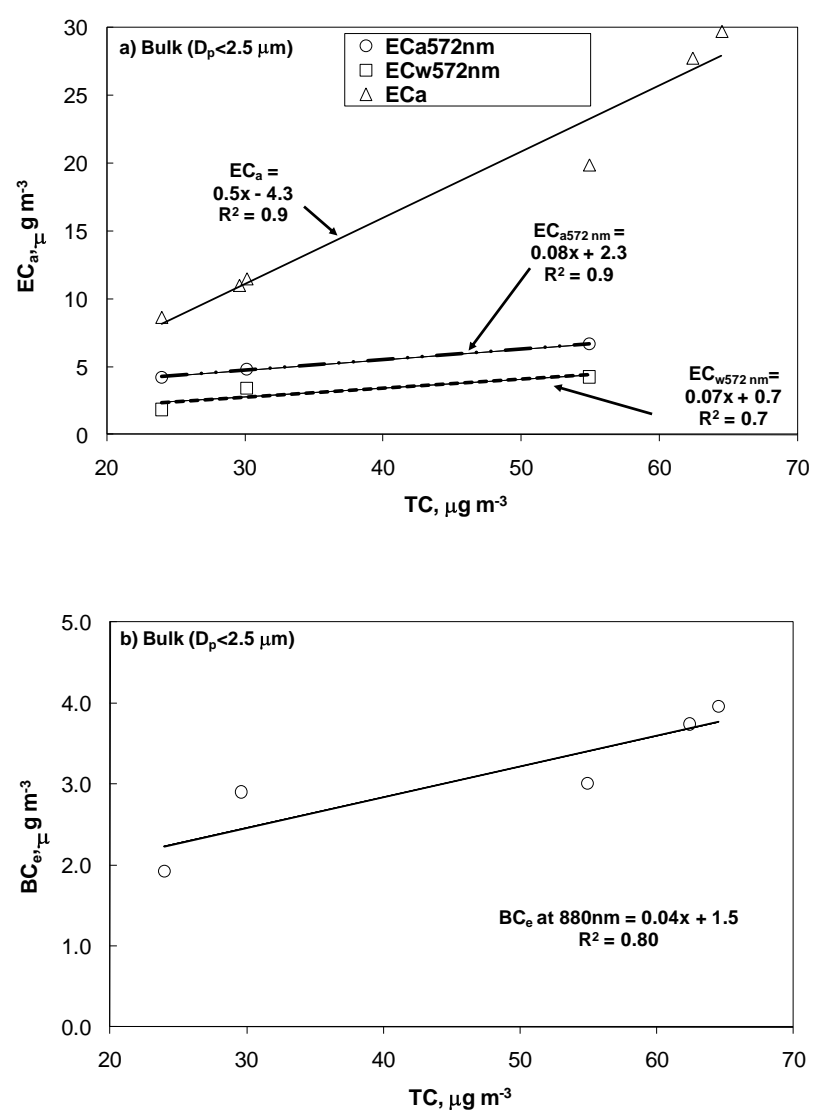

Fig. 6. (a) $\mathrm{EC}_{\mathrm{a}}\left(\mathrm{EC}_{\mathrm{a}}, \mathrm{EC}_{\mathrm{a} 572 \mathrm{~nm}}\right.$ (non-extracted), $\mathrm{EC}_{\mathrm{w}} 572 \mathrm{~nm}$ (extracted)) and (b) $\mathrm{BC}_{\mathrm{e}} 880 \mathrm{~nm}$ as a function of TC concentrations measured for the fine aerosol $\left(D_{p}<2.5 \mu \mathrm{m}\right)$.

other hand, the TOT instrument using the NIOSH temperature program yielded very low values, possibly because of overcompensation of charring artifacts. Nevertheless, the IMPROVE-TOR and NIOSH-TOT provide bounds for EC measurements and the ranges in concentrations are larger for some samples than others, depending on their charring potential and the extent of brown carbon. For example, brown carbon could be elevated and the charring substantial for smoldering-dominated samples (Chen et al., 2010, 2011; Chakrabarty et al., 2010). The NIOSH-TOT likely attributes more of the char and the brown carbon to OC than IMPROVE-TOR does, which may attribute these components more to $\mathrm{EC}_{\mathrm{a}}$. The optical $\left(\mathrm{BC}_{\mathrm{e}}\right)$ and the thermal methods with optical correction or water extraction gave mutually and internally consistent results with $\mathrm{EC}_{\mathrm{a}} / \mathrm{TC}$ or $\mathrm{BC}_{\mathrm{e}} / \mathrm{TC}$ ratios in the 0.04-0.08 range.

\subsection{Absorption spectral dependence}

The spectral dependence of the light attenuation was determined from optical data obtained during thermal analysis (see Sec. 2.3.1). Figure $3 \mathrm{~b}$ shows the spectral absorption of
Table 4. Comparison of the size-resolved Ångström exponent and the EC/TC ratios.

\begin{tabular}{rrrrr}
\hline$D_{p}(\mu \mathrm{m})$ & $\begin{array}{r}\text { Angström } \\
\text { exponent, } \alpha\end{array}$ & $\begin{array}{r}\text { Angström } \\
\text { exponent, } \alpha_{\mathrm{w}}\end{array}$ & $\mathrm{EC}_{\mathrm{a}} / \mathrm{TC}$ & $\mathrm{EC}_{\mathrm{w}} / \mathrm{TC}$ \\
\hline $0.05-0.1$ & $1.8^{*}$ & & $0.21^{*}$ & \\
$0.10-0.16$ & 2.0 & $0.7^{*}$ & 0.23 & $0.01^{*}$ \\
$0.16-0.27$ & 2.8 & 1.6 & 0.26 & 0.11 \\
$0.37-0.39$ & 3.9 & $1.2^{*}$ & 0.26 & 0.12 \\
$0.39-0.62$ & 3.1 & 1.5 & 0.10 & 0.10 \\
$0.62-0.97$ & 2.6 & 1.1 & 0.12 & 0.08 \\
$0.97-1.6$ & 2.1 & $1.3^{*}$ & 0.14 & 0.08 \\
\hline
\end{tabular}

Size-resolved Ångström exponent are represented by $\alpha$ for samples non-extracted and $\alpha_{\mathrm{W}}$ for samples extracted with water. These results were determined by using a thermaloptical analyzer (TOA) at $100^{\circ} \mathrm{C}$ and the reported averages are for three samples. The ones marked by $*$ are measurements for only one sample. $\mathrm{EC}_{\mathrm{a}}$ refers to apparent elemental carbon and the $\mathrm{EC}_{\mathrm{W}}$ to the elemental carbon after extracting with water.

the smoke aerosol sample from Fig. 3a at $100^{\circ} \mathrm{C}$ (see dashed line), before the evolution of any significant amount of carbon. The absorption Ångström exponent, $\alpha$, was estimated by fitting a power law to the data: $\sigma(\lambda)=K \lambda^{-\alpha}$, where $\sigma(\lambda)$ is the spectrally dependent attenuation, $K$ is a constant, $\lambda$ is the light wavelength. The value of $\alpha$ is a measure of the strength of the spectral variation in aerosol light absorption. The absorption Ångström exponent was $\sim 3.7$ for our untreated and $\sim 2.2$ for our water-extracted biomass burning aerosol samples (Fig. 3b). In contrast, motor vehicle generated aerosols, in which the only light absorbing species is $\mathrm{BC}_{\mathrm{e}}$, typically exhibit $\alpha \sim 1.0$ (Kirchstetter et al., 2004). The stronger spectral dependence of our biomass smoke samples was due to the presence of light absorbing OC (Brown Carbon, BrC) in addition to soot carbon (Schnaiter et al., 2003; Kirchstetter et al., 2004).

Water treatment removed much, but not all, of the sample OC that evolves below $400{ }^{\circ} \mathrm{C}$ (Fig. 3a). Similarly, the extraction with water greatly diminished the spectral dependence of the samples, but did not reduce it to $\sim 1.0$, as shown in Table 4. This table contains the absorption Ångström exponent results for the three samples that were measured by TOA (nominal $D_{p}$ between $0.1-2.4 \mu \mathrm{m}$ (stages $3-9$ )). The averages were between 1.8 and 3.9 for the non-extracted samples, and between 0.7 and 1.6 for the extracted samples. When the ratios of $\mathrm{EC}_{\mathrm{a}} / \mathrm{TC}$ and $\mathrm{EC}_{\mathrm{w}} / \mathrm{TC}$ at different sizes $(0.5-1.6 \mu \mathrm{m})$ were compared with the Ångström exponents ( $\alpha$ and $\alpha_{\mathrm{w}}$ ) in Table 4 , the stages with higher $\mathrm{EC}_{\mathrm{w}}$ fraction $\left(D_{p}\right.$ of 0.2 to $\left.0.6 \mu \mathrm{m}\right)$ showed higher Ångström exponents $\left(\mathrm{EC}_{\mathrm{W}} / \mathrm{TC}=0.09 \cdot \alpha_{\mathrm{w}}-0.04\right.$ and $r^{2}=0.94$, excluding one outlier). This was only observed for samples that were extracted with water and suggests that this behavior is probably due to the brown carbon left after the extraction process. 


\subsection{Contribution of the carbonaceous material to the total aerosol mass}

To determine the contribution of $\mathrm{OC}$ and $\mathrm{BC}_{\mathrm{e}}$ (our approximation of soot carbon, $\mathrm{C}_{\mathrm{soot}}$ ) to the total aerosol mass, we chose the $\mathrm{BC}_{\mathrm{e}}$ concentrations determined by the LTM as the best representation, since they were the most consistent with other methods (Sect. 3.1.4), and because there were more samples analyzed by this method than by the other techniques (Table 1).

Our OC concentrations averaged $43 \pm 18 \mu \mathrm{g} \mathrm{m}^{-3}$ (Table 1), accounting for $\sim 100 \%$ of the carbonaceous aerosol in our samples. This result is not corrected for the positive artifact observed when using the DLPI (Fig. 4a). For the carbonaceous fraction, the $\mathrm{OC}$ was estimated from the difference between $\mathrm{TC}$ and $\mathrm{BC}_{\mathrm{e}}$ (TC (Table 2: $33.6 \pm 31.7$ $\mu \mathrm{g} \mathrm{m}^{-3}$ ) $-\mathrm{BC}_{\mathrm{e}}$ (Table 1: $3.6 \pm 0.9 \mu \mathrm{g} \mathrm{m}^{-3}$ )) and converted to particle organic matter (POM) by using 1.8 as the conversion factor. This is a conservative OC conversion factor since aerosol heavily influenced by wood smoke can have conversion factors as high as 2.6 (Turpin and Lim, 2001). The inorganic fraction $\left(5.7 \pm 4.6 \mathrm{\mu g} \mathrm{m}^{-3}\right)$ was similar to the ones reported by Falkovich et al. (2005) and Fuzzi et al. (2007). It is important to state that the samples used here to obtain the average inorganic fraction $(n=4)$ and total aerosol mass $(n=6$; $\left.\left(63.9 \pm 56.6 \mu \mathrm{g} \mathrm{m}^{-3}\right)\right)$ were from aluminum substrates only.

Our results show that from the total estimated mass collected during the dry season, $84 \%$ was POM, $6 \%$ was the estimated $\mathrm{BC}_{\mathrm{e}}$, and $9 \%$ was the inorganic fraction. The residual mass was not significant. Comparing the measured gravimetric mass for $D_{p}<2.5 \mu \mathrm{m}$ to the mass reconstructed from measured species in our samples yields a closure within experimental uncertainties, indicating that for our sampling site the use of a conversion factor of 1.8 is appropriate for the conversion of OC to POM.

\subsection{Size-resolved $\mathrm{BC}_{\mathrm{e}}$ and $\mathrm{POM}$}

Figure 7 shows a comparison between TC concentrations collected with aluminum substrates and quartz fiber filters on the DLPI impactors. An exact comparison between the two DLPI substrates was not possible during this study, because sampling on quartz and aluminum could not be done simultaneously. However, when all TC size distributions collected during the dry period on the aluminum substrates $(n=7)$ and on the quartz fiber filters $(n=13)$ were compared, the TC concentrations for $D_{p}>\sim 0.4 \mu \mathrm{m}$ on quartz fiber filters were higher (by factors of 1.7 to 4.1 ) than the TC concentrations for the aluminum substrates. In other words, for aluminum $\mathrm{TC}$ is higher in fine diameters stages and lower on the coarse ones. Figure 7 shows that the size shift is less than one stage $(\sim 0.2 \mu \mathrm{m}$ for stages between $0.6-1.0 \mu \mathrm{m})$, i.e., significantly less than a factor of 2 . Also, even though there is a shift in size when using quartz filters, the shape of the size dis-

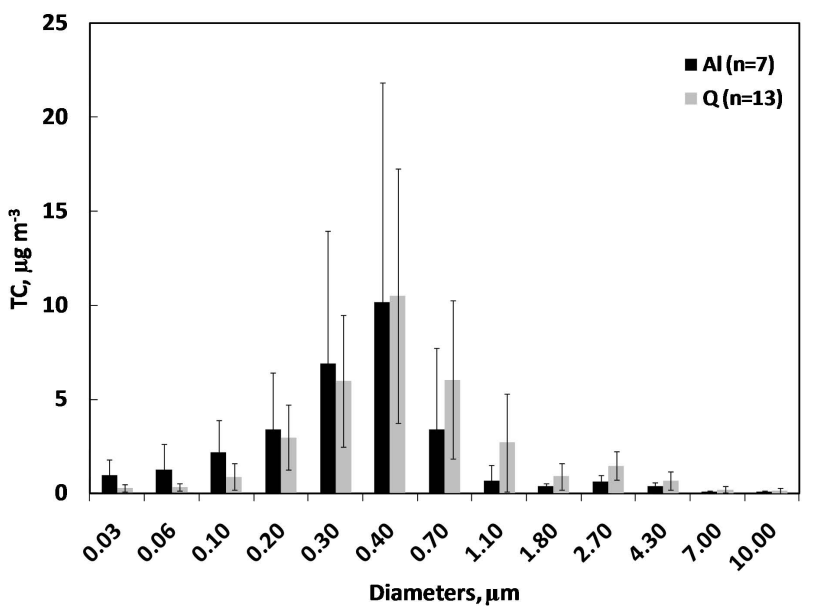

Fig. 7. Size-resolved averaged TC mass concentration when using aluminum substrates $(n=7)$ and quartz fiber filters $(n=13)$ for the DLPI sampler.

tribution does not differ between the data sets from the two substrates.

The size distributions for the carbonaceous fractions (OC and $\mathrm{BC}_{\mathrm{e}}$ ) are presented in Fig. 8. Results show a bimodal distribution for $\mathrm{BC}_{\mathrm{e}}$, with a fine mode at $D_{p} 0.4-0.6 \mu \mathrm{m}$ and a small coarse mode at $6.7-10 \mu \mathrm{m}$. The $\mathrm{BC}_{\mathrm{e}}$ in the coarse mode was probably due to an internal mixture of $\mathrm{BC}_{\mathrm{e}}$ and other coarse mode particles, to the absorption of light by large particles (e.g., primary biogenic aerosols) (Guyon et al., 2004), and possibly also to a small contribution by semivolatile adsorbed species to the absorption signal. The size distributions in Fig. 8 clearly show a bimodal pattern for OC with peaks in the submicron $\left(D_{p}=0.4-0.6 \mu \mathrm{m}\right)$ and supermicron $\left(D_{p}=2.4-4 \mu \mathrm{m}\right)$ size range. The size distribution of $\mathrm{BC}_{\mathrm{e}}$ was different from $\mathrm{OC}$ in the supermicron size, in part because the OC coarse mode may have been derived from plant debris, plant pollen and fungal spores, as suggested also by Fuzzi et al. (2007) for the size-resolved organic tracers of biogenic sources; or due to an internal mixture of $\mathrm{BC}_{\mathrm{e}}$ with primary and secondary organic aerosols.

The similar shape of the profile of the accumulation mode for both $\mathrm{OC}$ and $\mathrm{BC}_{\mathrm{e}}$ (Fig. 8) suggests that both species come from biomass burning. Previous studies have shown that the carbonaceous material (OC and EC) emitted from different sources showed an accumulation mode at $0.1 \mu \mathrm{m}$ for EC and 0.1-0.3 $\mu \mathrm{m}$ for OC from diesel (Kerminen et al., 1997), 0.1-0.2 $\mu \mathrm{m}$ for POM and EC from cars (Kleeman et al., 2000), at $0.2-0.3 \mu \mathrm{m}$ in the volume size distribution from fresh biomass burning, and at $0.3-0.4 \mu \mathrm{m}$ in the volume size distribution from aged smoke (Reid et al., 2005). The submicron size range we are reporting here is usually called the droplet mode $(0.4-0.6 \mu \mathrm{m})$. However, this can also be due to the uncertainties in particle size when using quartz fiber filters as substrates in an impactor. 


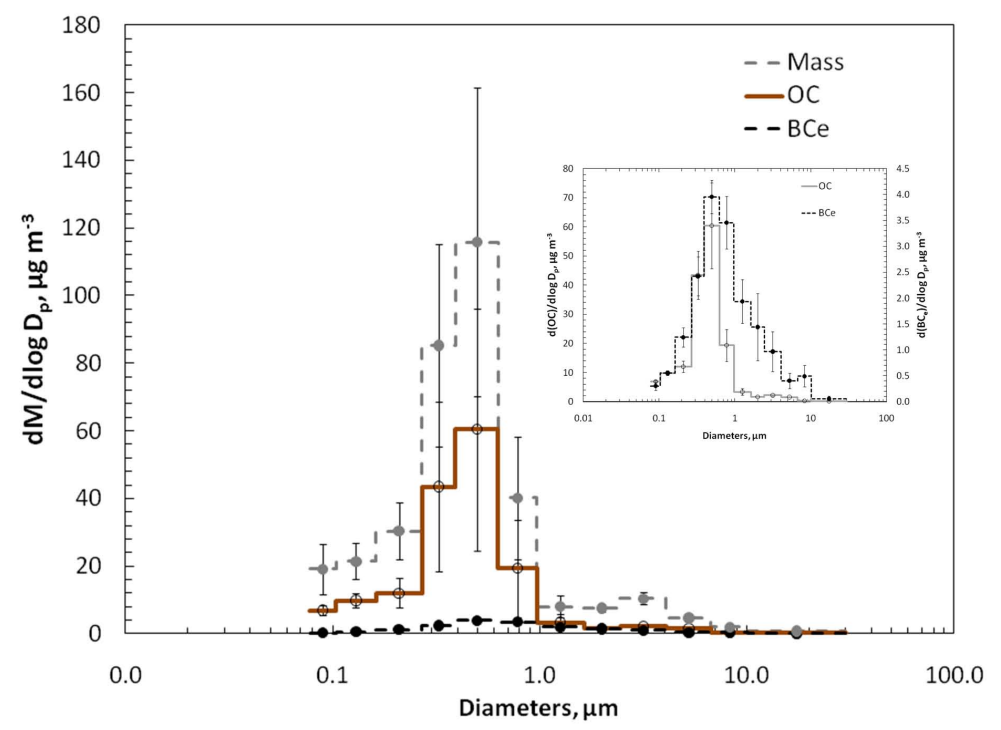

Fig. 8. Size distribution of the average mass, $\mathrm{OC}$ and $\mathrm{BC}_{\mathrm{e}}$ concentrations. To show the size distributions of $\mathrm{OC}$ and $\mathrm{BC}$ e more clearly, they are shown at different scales in the insert. The size distribution for the mass concentrations are the average for all samples collected on aluminum foil substrates during the dry period $(n=6)$. The size distribution for $\mathrm{OC}$ and $\mathrm{BC}_{\mathrm{e}}$ concentrations were collected on quartz fiber filters $(n=5)$. Error bars here represent the standard error (standard deviation divided by the number of samples).

Figure 9a demonstrates that OC mass concentrations were higher during the night. This increase in the fine fraction during night was mainly due to continued emissions into the shallow nocturnal boundary layer (Rissler et al., 2006), to the condensation of volatile compounds into the aerosol phase at the lower temperatures $\left(<25^{\circ} \mathrm{C}\right)$, and to high nocturnal relative humidity ( $\sim 100 \%)$ (Trebs et al., 2005). OC enrichment was also observed in the size-resolved low-molecularweight WSOC fractions measured by Falkovich et al. (2005) and Fuzzi et al. (2007).

Observation of higher concentrations for all stages below $0.39 \mu \mathrm{m}$ (Fig. 9a) may have been due to adsorption of gases (positive and negative artifacts) on the quartz filter for those particular sizes and especially during daytime. The $\mathrm{OC}$ gases could have been derived from the volatilization of POM on the coarser stages in the course of the actual sampling because of the higher temperatures during the day. Also, there may simply not be much very fine POM during the night because it may have grown to larger particles at the much higher $\mathrm{RH}$ during the night. Fine POM during the dry and transition periods was around 60-70\% soluble in water (Decesari et al., 2006). Thus, the POM can grow to larger sizes at high RH, as encountered during the night.

However, Fig. 9 b shows that the fine mode mass of $\mathrm{BC}_{\mathrm{e}}$ during day time was almost the same as during night time, suggesting that, at least for this sample period, only little soot carbon is emitted at night. Nevertheless, observations of diurnal samples from the aethalometer and $\mathrm{EC}_{\mathrm{a}}$ concentrations from HVDS reported by Decesari et al. (2006) show the same behavior as for the OC concentrations. The size distributions of both $\mathrm{OC}$ and $\mathrm{BC}_{\mathrm{e}}$ are shifted slightly towards larger sizes at night, possibly due to some condensation of organic and inorganic constituents, as well as some water uptake.

In order to assess the role of water uptake on the sizing of our DLPI samples, we use the growth factors measured by Rissler et al. (2006). During the dry season it was found that the non-hygroscopic mode dominates, and we can assume that a particle growth factor, GF (80\%), of 1.10 to 1.15 is representative of the total aerosol. For the average daytime $\mathrm{RH}$ of $70 \%$, the wet diameters are thus about $4 \%$ greater than the dry diameters. At night, it becomes very difficult to provide an accurate estimate, because humidities can exceed $90 \%$, and the growth becomes very steep in the RH region between 90 and $100 \%$. To get an idea of the range to be expected, the growth of a particle at 90, 95, and $100 \%$ has been calculated. If a $100 \mathrm{~nm}$ particle is assumed, a hygroscopicity coefficient of $\kappa=0.04$ is sufficient to obtain a GF $(90 \%)=1.09$. This would represent a lower limit for the particle hygroscopicity. The GF at 95 and $100 \%$ for these particles would be 1.16 and 1.59 . If, on the other hand, a $500 \mathrm{~nm}$ particle with a $\kappa=0.2$ (which has been observed for aged smoke) is assumed, we get $\mathrm{GF}=1.4,1.7$, and 6.9 for 90,95 , and $100 \%$. In conclusion, the GF becomes very strongly dependent of RH, $\kappa$, and particle size as one approaches $100 \%$ $\mathrm{RH}$. For the impactor, this means that the smallest particles are going to be deposited mostly on the same stage even at $100 \%$, while the largest $\left(D_{p}<4 \mu \mathrm{m}\right)$ and most hygroscopic particles can move up as much as two stages. To have more precise results would require very accurate knowledge of the hygroscopicity in the accumulation mode, and of the RH in 

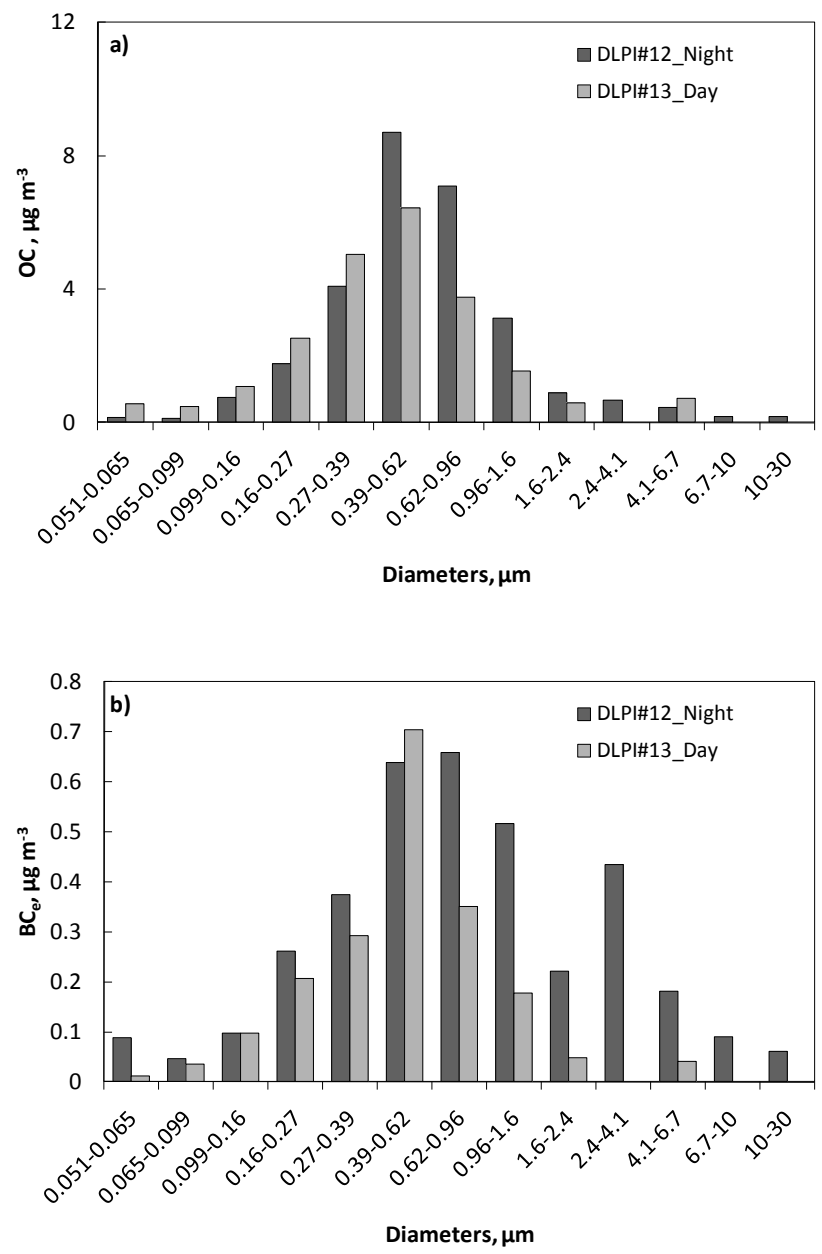

Fig. 9. Size-resolved nighttime (DLPI\# 12) and daytime (DLPI\# 13) (a) OC and (b) $\mathrm{BC}_{\mathrm{e}}$ concentrations for selected samples. These examples show the diurnal variation of the size-resolved $\mathrm{OC}$ and $\mathrm{BC}_{\mathrm{e}}$ during SMOCC-2002.

the impactor, neither of which were measured. Nevertheless, the effect of water uptake during the day is small relative to the size resolution of the impactor, while the effect during the night is not possible to estimate accurately enough with the data we have, but could easily be large enough to explain the observed shifts.

\section{Conclusions}

In this study, as part of the LBA-SMOCC-2002 field experiment, we determined the carbonaceous fraction in aerosol samples dominated by biomass burning, using different analytical methods. Results from thermal, thermal-optical (TOA), and optical techniques applied to water-extracted and non-extracted samples showed that most of the aerosol mass was due to carbonaceous material, and that the fine fraction was greater than the coarse fraction. TOA showed that the
WSOC fraction was at least partly pyrolyzed during the analysis. Also, for specific sizes $\left(D_{p}: 0.2-0.3\right.$ and $\left.0.4-0.6 \mu \mathrm{m}\right)$, TOA showed the existence of residual OC on water extracted samples. This contradicts the assumption sometimes made for analysis of aerosols from biomass burning sources that only EC remains after water extraction.

Different techniques commonly used for determining $\mathrm{EC}_{\mathrm{a}}$ produced different results, demonstrating the difficulties of separating EC from OC in biomass burning samples. Combustion of biomass produces $\mathrm{EC}_{\mathrm{a}}$ and refractory $\mathrm{OC}$ with similar thermal, oxidative and optical characteristics.

Different temperature programs showed significant differences for the $\mathrm{OC} / \mathrm{EC}_{\mathrm{a}}$ split. For example, measurements with the semi-continuous $\mathrm{R} \& \mathrm{P}$ carbon monitor yielded $\mathrm{EC}_{\mathrm{a}}$ concentrations that were more than three times higher than for most other systems. In contrast, the NIOSH TOT method gave $\mathrm{EC}_{\mathrm{a}}$ concentrations that were more than three times lower than most other systems. $\mathrm{EC}_{\mathrm{a}}$ and $\mathrm{BC}_{\mathrm{e}}$ contributed 4 to $8 \%$ to the total mass concentration. The POM contribution was more than $85 \%$.

TC and POM mass-size distributions were bimodal with the submicron fraction significantly larger than the coarse fraction. $\mathrm{BC}_{\mathrm{e}}$ showed the expected mode in the submicron size and a mode in the coarse size, possibly due to an internal mixture of $\mathrm{BC}_{\mathrm{e}}$ and other coarse particles, which requires further study. Diurnal variations of OC were also observed. The different diurnal behavior of the $\mathrm{OC}$ and $\mathrm{BC}_{\mathrm{e}}$ size distributions is related to differences caused by variations in temperature, relative humidity, and the depth of the boundary layer.

We conclude that LTM, IMPROVE-TOR, and TOA together with water-extraction provided comparable estimates of $\mathrm{EC}_{\mathrm{a}}$ and $\mathrm{BC}_{\mathrm{e}}$ concentrations and size distributions of aerosols dominated by biomass burning in the smoldering phase, whereas NIOSH-TOT provided substantially lower estimates.The use of these techniques can reduce the uncertainties in the estimation of $\mathrm{EC}_{\mathrm{a}}$ or $\mathrm{BC}_{\mathrm{e}}$, and, therefore, provide more reliable data to be used by global and regional climate models that deal with the impact of biomass burning.

Acknowledgements. This work was carried out within the framework of the Smoke, Aerosols, Clouds, Rainfall, and Climate (SMOCC) project, a European contribution to the Large-Scale Biosphere-Atmosphere Experiment in Amazonia (LBA). It was financially supported by the NASA-Puerto Rico Space Grant Consortium and the Max Planck Society (MPG). Willy Maenhaut also thanks the Belgian Federal Science Policy Office for research support. We are thankful to all members of the LBA-SMOCC-2002 team, to Susimar González for her help in the collection of samples, and to Pascal Guyon for some of the thermal analyses.

Edited by: R. Krejci 


\section{References}

Andreae, M. O.: Soot carbon and excess fine potassium: Longrange transport of combustion-derived aerosols, Science, 220, 1148-1151, 1983.

Andreae, M. O. and Crutzen, P.: Atmospheric Aerosols: Biogeochemical sources and role in the atmospheric chemistry, Science, 276, 1052-1058, 1997.

Andreae, M. O. and Gelencsér, A.: Black carbon or brown carbon? The nature of light-absorbing carbonaceous aerosols, Atmos. Chem. Phys., 6, 3131-3148, doi:10.5194/acp-6-3131-2006, 2006.

Andreae, M. O., Artaxo, P., Brandão, C., Carswell, F. E., Ciccioli, P., da Costa, A. L., Culf, A. D., Esteves, J. L., Gash, J. H. C., Grace, J., Kabat, P., Lelieveld, J., Malhi, Y., Manzi, A. O., Meixner, F. X., Nobre, A. D., Nobre, C., Ruivo, M. D. L. P., Silva-Dias, M. A., Stefani, P., Valentini, R., Jouanne, J. von, and Waterloo, M. J.: Biogeochemical cycling of carbon, water, energy, trace gases and aerosols in Amazonia: The LBA-EUSTACH experiments, J. Geophys. Res., 107, D20, doi:10.1029/2001JD000554, 2002.

Andreae, M. O., Rosenfeld, D., Artaxo, P., Costa, A. A., Frank, G. P., Longo, K. M., and Silva-Dias, M. A. F.: Smoking rain clouds over the Amazon, Science, 303, 1337-1342, 2004.

Artaxo, P., Fernandez, E. T., Martins, J. V., Yamasoe, M. A., Hobbs, P. V., Maenhaut, W., Longo, K. M., and Castanho, A.: Large scale aerosol source apportionment in Amazonia, J. Geophys. Res., 103, 31837-31848, 1998.

Artaxo, P., de Campos, R. C., Fernandez, E. T., Martins, J. V., Xiao, Z., Lindqvist, O., Fernandez-Jimenez, M. T., and Maenhaut, W.: Large scale mercury and trace element measurements in the Amazon Basin, Atmos. Environ., 34, 4085-4096, 2000.

Artaxo, P., Vanderlei Martins, J., Yamasoe, M. A., Procopio, A. S., Pauliquevis, T. M., Andreae, M. O., Guyon, P., Gatti, L. V., and Cordova Leal, A. M.: Physical and chemical properties of aerosols in the wet and dry seasons in the Rondônia, Amazonia, J. Geophys. Res., 107, D20, doi:10.1029/2001JD000666, 2002.

Barth, M., Mc Fadden, J., Sun, J., Wiedinmyer, C., Chuang, P., Collins, D., Griffin, R., Hannigan, M., Karl, T., Kim, S., LasherTrapp, S., Levis, S., Litvak, M., Mahowald, N., Moore, K., Nandi, S., Nemitz, E., Nenes, A., Potosnak, M., Raymond, T., Smith, J., Still, C., and Stroud, C.: Coupling between land ecosystems and the atmospheric hydrologic cycle through biogenic aerosol pathways, BAMS, 1738-1742, 2005.

Birch, M. E. and Cary, R. A.: Elemental carbon-based method for monitoring occupational exposures to particulate diesel exhaust, Aerosol. Sci. Technol., 25, 221-241, 1996.

Chakrabarty, R. K., Moosmüller, H., Chen, L.-W. A., Lewis, K., Arnott, W. P., Mazzoleni, C., Dubey, M. K., Wold, C. E., Hao, W. M., and Kreidenweis, S. M.: Brown carbon in tar balls from smoldering biomass combustion, Atmos. Chem. Phys., 10, 6363-6370, doi:10.5194/acp-10-6363-2010, 2010.

Chen, L.-W. A., Chow, J. C., Watson, J. G., Moosmüller, H., Arnott, P. W.: Modeling reflectance and transmittance of quartz-fiber filter samples containing elemental carbon particles: Implication for thermal/optical analysis, J. Aerosol. Sci., 35, 765-780, 2004.

Chen, L.-W. A., Verburg, P., Shackelford, A., Zhu, D., Susfalk, R., Chow, J. C., and Watson, J. G.: Moisture effects on carbon and nitrogen emission from burning of wildland biomass, Atmos. Chem. Phys., 10, 6617-6625, doi:10.5194/acp-10-6617-
2010, 2010.

Cheng, Y., Zheng, M., He, K., Chen, Y., Yana, B., Russell, A. G., Shi, W., Jiao, Z., Sheng, G., Fu, J., Edgerton, E. S.: Comparison of two thermal-optical methods for the determination of organic carbon and elemental carbon: Results from the southeastern United States, Atmos. Environ., 45, 1913-1918, doi:10.1016/j.atmosenv.2011.01.036, 2011.

Chow, J. C., Watson, J. G., Pritchett, L. C., Pierson, W. R., Frazier, C. A., and Purcell, R. G.: The DRI Thermal/Optical Reflectance carbon analysis system: Description, evaluation and applications in U.S. air quality studies, Atmos. Environ., 27A, 8, 1185-1201, 1993.

Chow, J. C., Watson, J. G., Crow, D., Lowenthal, D. H., and Merrifield, T., Comparison of IMPROVE and NIOSH carbon measurements, Aerosol. Sci. Technol., 34, 23-34, 2001.

Chow, J. C., Watson, J. G., Chen, L. W. A., Arnott, W. P., and Moosmüller, H.: Equivalence of elemental carbon by thermal/optical reflectance and transmittance with different temperature protocols, Environ. Sci. Technol., 38, 4414-4422, 2004.

Chow, J. C., Watson, J. G., Chen, L.-W. A., Paredes-Miranda, G., Chang, M.-C. O., Trimble, D., Fung, K. K., Zhang, H., and Zhen Yu, J.: Refining temperature measures in thermal/optical carbon analysis, Atmos. Chem. Phys., 5, 2961-2972, doi:10.5194/acp5-2961-2005, 2005.

Chow, J. C., Watson, J. G., Chen, L.-W.A., Chang, M. C. O., Robinson, N. F., Trimble, D., and Kohl, S. D.: The IMPROVE_A temperature protocol for thermal/optical carbon analysis: Maintaining consistency with a long-term database, J. Air Waste Manage. Assoc., 57, 9, 1014-1023, 2007.

Decesari, S., Fuzzi, S., Facchini, M. C., Mircea, M., Emblico, L., Cavalli, F., Maenhaut, W., Chi, X., Schkolnik, G., Falkovich, A., Rudich, Y., Claeys, M., Pashynska, V., Vas, G., Kourtchev, I., Vermeylen, R., Hoffer, A., Andreae, M. O., Tagliavini, E., Moretti, F., and Artaxo, P.: Characterization of the organic composition of aerosols from Rondnia, Brazil, during the LBASMOCC 2002 experiment and its representation through model compounds, Atmos. Chem. Phys., 6, 375-402, doi:10.5194/acp6-375-2006, 2006.

Dod, R. L., Rosen, H., and Novakov T.: Optico-thermal analysis of the carbonaceous fraction of aerosol particles, Rep. LBL-8696, Lawrence Berkeley Lab., Berkeley, Calif., 1979.

Dong, Y., Hays, M. D., Smith, N. D., and Kinsey, J. S.: Inverting cascade impactor data for size-resolved characterization of fine particulate source emissions, J. Aerosol. Sci., 35, 1497-1512, 2004.

Eatough, D. J., Wadsworth, A., Eatough, D. A., Crawford, J. W., Hansen, L. D., and Lewis, E. A.: A multiple-system, multichannel diffusion denuder sampler for the determination of fineparticulate organic material in the atmosphere, Atmos. Environ., 27, 1213-1219, 1993.

Echalar, F., Artaxo, P., Martins, J. V., Yamasoe, M., Gerab, F., Maenhaut, W., and Holben, B.: Long-term monitoring of atmospheric aerosols in the Amazon Basin: Source identification and apportionment, J. Geophys. Res., 103, 31849-31864, 1998.

EPA (US Environmental Protection Agency) Publication: Particle pollution and your health, 452/F-03-001, available at: http: //www.epa.gov/airnow//particle/pm-color.pdf, 2003.

Falkovich, A. H., Graber, E. R., Schkolnik, G., Rudich, Y., Maenhaut, W., and Artaxo, P.: Low molecular weight organic acids 
in aerosol particles from Rondônia, Brazil, during the biomassburning, transition and wet periods, Atmos. Chem. Phys., 5, 781797, doi:10.5194/acp-5-781-2005, 2005.

Ferek, R. J., Reid, J. S., Hobbs, P. V., Blake, D. R., and Liousse, C.: Emission factors of hydrocarbons, halocarbons, trace gases and particles from biomass burning in Brazil, J. Geophys. Res., 103, 32 107-32 118, 1998.

Formenti, P., Elbert, W., Maenhaut, W., Haywood, J., Osborne, S., and Andreae, M. O.: Inorganic and carbonaceous aerosols during the Southern African Regional Science Initiative (SAFARI 2000) experiment: Chemical characteristics, physical properties, and emission data for smoke from African biomass burning, J. Geophys. Res., 108(D13), 8488, doi:10.1029/2002JD002408, 2003.

Fuzzi, S., Decesari, S., Facchini, M. C., Cavalli, F., Emblico, L., Mircea, M., Andreae, M. O., Trebs, I., Hoffer, A., Guyon, P., Artaxo, P., Rizzo, L. V., Lara, L. L., Pauliquevis, T., Maenhaut, W., Raes, N., Chi, X., Mayol-Bracero, O. L., Soto-García, L. L., Claeys, M., Kourtchev, I., Rissler, J., Swietlicki, E., Tagliavini, E., Schkolnik, G., Falkovich, A. H, Rudich, Y., Fisch, G., and Gatti, L. V.: Overview of the inorganic and organic composition of size-segregated aerosol in Rondônia, Brazil, from the biomass-burning period to the onset of the wet season, J. Geophys. Res., 112, D01201, doi:10.1029/2005JD006741, 2007.

Graham, B., Mayol-Bracero, O. L., Guyon, P., Roberts, G. C., Decesari, S., Facchini, M. C., Artaxo, P., Maenhaut, W., Köll, P., and Andreae, M. O.: Water-soluble organic compounds in biomass burning aerosols over Amazonia, 1. Characterization by NMR and GC-MS, J. Geophys. Res., 107, D20, doi:10.1029/2001JD000336, 2002.

Gundel, L. A., Dod, R. L., Rosen, H., and Novakov, T.: The relationship between optical attenuation and black carbon concentrations for ambient and source particles, Sci. Total Environ., 36, 197-202, 1984.

Guyon, P., Graham, B., Roberts, G., Mayol-Bracero, O., Maenhaut, W., Artaxo, P., and Andreae, M.: In-canopy gradients, composition, sources, and optical properties of aerosol over the Amazon forest, J. Geophys. Res., 108, D18, 4591, doi:10.1029/2003JD003465, 2003.

Guyon, P., Graham, B., Roberts, G. C., Mayol-Bracero, O. L., Maenhaut, W., Artaxo, P., Andreae, M. O.: Sources of optically active aerosol particles over the Amazon forest, Atmos. Environ., 38, 1039-1051, 2004.

Guyon, P., Frank, G. P., Welling, M., Chand, D., Artaxo, P., Rizzo, L., Nishioka, G., Kolle, O., Fritsch, H., Silva Dias, M. A. F, Gatti, L. V., Cordova, A. M., and Andreae, M. O.: Airborne measurements of trace gas and aerosol particle emissions from biomass burning in Amazonia, Atmos. Chem. Phys., 5, 29893002, doi:10.5194/acp-5-2989-2005, 2005.

Hadley, O., Corrigan, C., and Kirchstetter, T.: Modified thermaloptical analysis using spectral absorption selectivity to distinguish black carbon from pyrolized organic carbon, Environ. Sci. Technol., 42, 8459-8464, 2008.

Hansen, A. D. A., Rosen, H., and Novakov, T.: The aethalometer-an instrument for the real-time measurement of optical absorption by aerosol particles, Sci. Total Environ., 36, 91-196, 1984.

Herckes, P., Eregling, G., Kreidenweis, S., and Collett, J.: Particle size distributions of organic aerosol constituents during the 2002 Yosemite aerosol characterization study, Environ. Sci. Technol., 40, 4554-4562, 2006.
Hitzenberger, R., Berner, A., Galambos, Z., Maenhaut, W., Cafmeyer, J., Schwarz, J., Müller, K., Spindler, G., Wieprecht, W., Acker, K., Hillamo, R., and Mäkelä, T.: Intercomparison of methods to measure the mass concentration of the atmospheric aerosol during INTERCOMP2000-influence of instrumentation and size cuts, Atmos. Environ., 38, 6467-6476, 2004.

Hobbs, P. V., Reid, J. S., Kotchenruther, R. A., Ferek, R. J., and Weiss, R.: Direct radiative forcing by smoke from biomass burning, Science, 272, 1776-1778, 1997.

Hoffer, A., Gelencsér, A., Guyon, P., Kiss, G., Schmid, O., Frank, G. P., Artaxo, P., and Andreae, M. O.: Optical properties of humic-like substances (HULIS) in biomass-burning aerosols, Atmos. Chem. Phys., 6, 3563-3570, doi:10.5194/acp-6-3563-2006, 2006 .

Hoffer, A., Gelencsér, A., Blazsó, M., Guyon, P., Artaxo, P., and Andreae, M. O.: Diel and seasonal variations in the chemical composition of biomass burning aerosol, Atmos. Chem. Phys., 6, 3505-3515, doi:10.5194/acp-6-3505-2006, 2006 b.

Jacobson, M. Z.: Strong radiative heating due to the mixing state of black carbon in atmospheric aerosols, Nature, 409, 695-697, 2001.

Kerminen, V.-M., Makela, T. E., Ojanen, C. H., Hillamo, R. E., Vilhunen, J. K., Rantanen, L., Havers, N., Von Bohlen, A., and Klockow, D.: Characterisation of the particulate phase in the exhaust of a diesel car, Environ. Sci. Technol., 31, 1883-1889, 1997.

Kleeman, M. J., Schauer, J. J., and Cass, G. R.: Size and composition distribution of fine particulate matter emitted from motor vehicles, Environ. Sci. Technol., 34, 1132-1142, 2000.

Kirchstetter, T. W. and Novakov, T.: Controlled generation of black carbon particles from a diffusion flame and applications in evaluating black carbon measurement methods, Atmos. Environ., 41, 1874-1888, 2007.

Kirchstetter, T. W., Corrigan, C. E., and Novakov, T.: Laboratory and field investigation of the adsorption of gaseous organic compounds onto quartz filters, Atmos. Environ., 35, 1663-1671, 2001.

Kirchstetter, T. W., Novakov, T., Hobbs, P. V., and Magi, B., Airborne measurements of carbonaceous aerosols in southern Africa during the dry, biomass burning season: J. Geophys. Res., 108(D13), 8476, doi:10.1029/2002JD002171, 2003.

Kirchstetter, T. W., Novakov, T., and Hobbs, P. V.: Evidence that the spectral dependence of light absorption by aerosols is affected by organic carbon, J. Geophys. Res., 109, D21208, 25, doi:10.1029/2004JD004999S, 2004.

Kirkman, G. A., Gut, A., Ammann, C., Gatti, L. V., Cordova, A. M., Moura, M. A. L., Andreae, M. O., and Meixner, F. X.: Surface exchange of nitric oxide, nitrogen dioxide, and ozone at a cattle pasture in Rondonia, Brazil, J. Geophys. Res., 107(D20), 8083, doi:10.1029/2001JD000523, 2002.

Koren, I., Kaufman, Y. J., Remer, L. A., and Martins, J. V.: Measurement of the effect of Amazon smoke on inhibition of cloud formation, Science, 303, 1342-1345, 2004.

Liousse, C., Cachier, H., and Jennings, S. G.: Optical and thermal measurements of black carbon aerosol content in different environments: Variation of the specific attenuation cross- section, Atmos. Environ., 27, 1203-1211, 1993.

Marjamäki, M., Lemmetty, M., and Keskinen, J.: ELPI response and data reduction I: response function, Aerosol. Sci. Technol., 
39, 575-582, 2005.

Mader, B. T., Schauer, J. J., Seinfeld, J. H., Flagan, R. C., Yu, J. Z., Yang, H., Lim, Ho-Jin, Turpin, B. J., Deminter, J. T., Heidemann, G., Bae, M. S., Quinn, P., Bates, T., Eatough, D. J., Huebert, B. J., Bertram, T., and Howell, S.: Sampling methods used for the collection of particle phase organic and elemental carbon during ACE-Asia, Atmos. Environ., 37, 1435-1449, 2003.

Martin, S. T., Andreae, M. O., Artaxo, P., Baumgardner, D., Chen, Q., Goldstein, A. H., Guenther, A., Heald, C. L., MayolBracero, O. L., McMurry, P. H., Pauliquevis, T., Pöschl, U., Prather, K. A., Roberts, G. C., Saleska, S. R., Dias, M. A. S., Spracklen, D., Swietlicki, E., and Trebs, I.: Sources and properties of Amazonian aerosol particles, Rev. Geophys., 48, RG2002, doi:10.1029/2008RG000280, 2010.

Martins, J. V., Artaxo, P., Liousse, C., Reid, J. S., Hobbs, P. V., and Kaufman, Y. J.: Effects of black carbon content, particle size, and mixing on light absorption by aerosols from biomass burning in Brazil, J. Geophys. Res., 103, 32041-32050, 1998a.

Martins, J. V., Hobbs, P. V., Weiss, R. E., and Artaxo, P.: Sphericity and morphology of smoke particles from biomass burning in Brazil, J. Geophys. Res., 103, 32051-32057, 1998 b.

Mayol-Bracero, O. L., Guyon, P., Graham, B., Andreae, M. O., Decesari, S., Facchini, M. C., Fuzzi, S., and Artaxo, P.: Water-soluble organic compounds in biomass burning aerosols over Amazonia, 2. Apportionment of the chemical composition and importance of the polyacidic fraction, J. Geophys. Res., 107(D20), 8091, doi:10.1029/2001JD000522, 2002a.

Mayol-Bracero, O. L., Gabriel, R., Andreae, M. O., Kirchstetter, T. W., Novakov, T., and Streets, D. G.: Carbonaceous aerosols over the Indian Ocean during INDOEX: Chemical characterization, optical properties, and probable sources, J. Geophys. Res., 107(D19), 8030, doi:10.1029/2000JD000039, 2002b.

Mircea, M., Facchini, M. C., Decesari, S., Cavalli, F., Emblico, L., Fuzzi, S., Vestin, A., Rissler, J., Swietlicki, E., Frank, G., Andreae, M. O., Maenhaut, W., Rudich, Y., and Artaxo, P.: Importance of the organic aerosol fraction for modeling aerosol hygroscopic growth and activation: a case study in the Amazon Basin, Atmos. Chem. Phys., 5, 3111-3126, doi:10.5194/acp-53111-2005, 2005.

Müller, T., Henzing, J. S., de Leeuw, G., Wiedensohler, A., Alastuey, A., Angelov, H., Bizjak, M., Collaud Coen, M., Engström, J. E., Gruening, C., Hillamo, R., Hoffer, A., Imre, K., Ivanow, P., Jennings, G., Sun, J. Y., Kalivitis, N., Karlsson, H., Komppula, M., Laj, P., Li, S.-M., Lunder, C., Marinoni, A., Martins dos Santos, S., Moerman, M., Nowak, A., Ogren, J. A., Petzold, A., Pichon, J. M., Rodriquez, S., Sharma, S., Sheridan, P. J., Teinilä, K., Tuch, T., Viana, M., Virkkula, A., Weingartner, E., Wilhelm, R., and Wang, Y. Q.: Characterization and intercomparison of aerosol absorption photometers: result of two intercomparison workshops, Atmos. Meas. Tech., 4, 245-268, doi:10.5194/amt-4-245-2011, 2011.

NIOSH: Elemental carbon (diesel): in: Elemental carbon (diesel particulate). NIOSH manual of analytical, NIOSH manual of analytical methods, National Institute of Occupational Safety and Health, Cincinnati, OH, 1996.

NIOSH Method 5040 issue 3 (interim): elemental carbon (diesel exhaust), in: Elemental carbon (diesel particulate). NIOSH manual of analytical NIOSH manual of analytical methods, National Institute of Occupational Safety and Health, Cincinnati, OH, 1999.
Novakov, T.: Microchemical characterization of aerosols, in Nature, Aim and Methods of Microchemistry, edited by: Malissa, H., Grasserbaure, M., and Belcher, R., 141-165, Springer-Verlag, New York, USA, 1981.

Novakov, T. and Corrigan, C. E.: Thermal characterization of biomass smoke particles, Mikrochim. Acta, 119, 157-166, 1995.

Novakov, T., Menon, S., Kirchstetter, T. W., Koch, D., and Hansen, J. E.: Aerosol organic carbon to black carbon ratios: Analysis of published data and implications for climate forcing, J. Geophys. Res., 110, D21205, doi:10.1029/2005JD005977, 2005.

Park, K., Chow, J. C., Watson, J. G., Trimble, D. L., Doraiswamy, P., Arnott, W. P., Stroud, K. R., Bowers, K., Bode, R., Petzold, A., and Hansen, A. D. A.: Comparison of continuous and filterbased carbon measurements at the Fresno Supersite, J. Air Waste Manage., 56(4), 474-491, 2006.

Peterson, M. R. and Richards, M. H.: Thermal-optical transmittance analysis for organic, elemental, carbonate, total carbon, and OCX2 in PM2.5 by the EPA/NIOSH method, in: Proceedings, Symposium on Air Quality Measurement Methods and Technology-2002, edited by: Winegar, E. D. and Tropp, R. J., Air \& Waste Management Association, Pittsburgh, PA, 83-1-8319, 2002.

Pope, C. A., and Dockery, D. W.: Health effects of fine particulate air pollution: Lines that connect, J. Air Waste Manage., 56, 709742, 2006.

Pöschl, U.: Aerosol particle analysis: challenges and progress, Anal. Bioanal. Chem., 375, 30-32, 2003.

Ramachandran, G. and Kandlikar, M.: Bayesian analysis for the inversion of aerosols from impaction data, J. Aerosol. Sci., 27, 1099-1112, 1996.

Reid, J. S., Hobbs, P. V., Ferek, R. J., Blake, D. R., Martins, J. V., Dunlap, M. R., and Liousse, C.: Physical, chemical, and optical properties of regional hazes dominated by smoke in Brazil, J. Geophys. Res., 103, 32059-32080, 1998.

Reid, J. S., Koppmann, R., Eck, T. F., and Eleuterio, D. P.: A review of biomass burning emissions part II: intensive physical properties of biomass burning particles, Atmos. Chem. Phys., 5, 799825, doi:10.5194/acp-5-799-2005, 2005.

Rissler, J., Vestin, A., Swietlicki, E., Fisch, G., Zhou, J., Artaxo, P., and Andreae, M. O.: Size distribution and hygroscopic properties of aerosol particles from dry-season biomass burning in Amazonia, Atmos. Chem. Phys., 6, 471-491, doi:10.5194/acp6-471-2006, 2006.

Roberts, G., Artaxo, P., Zhou, J., Swietlicki, E., and Andreae, M. O., Sensitivity of CCN spectra on chemical and physical properties of aerosol: A case study from the Amazon Basin, J. Geophys. Res., 107, 8070, doi:10.1029/2001JD000583, 2002.

Robinson, A. L., Donahue, N. M., Shrivastava, M. K., Weitkamp, E. A., Sage, A. M., Grieshop, A. P., Lane, T. E., Pierce, J. R., and Pandis, S. N.: Rethinking organic aerosols: semivolatile emissions and photochemical aging, Science, 315, 1259-1262, 2007.

Rosenfeld, D.: TRMM Observed first direct evidence of smoke from forest fires inhibiting rainfall, Geophys. Res. Lett., 26, 3105-3108, 1999.

Rosenfeld, D., Lohmann, U., Raga, G. B., O’Dowd, C. D., Kulmala, M., Fuzzi, S., Reissell, A.: Flood or drought: How do aerosols affect precipitation?, Science, 321, 1309-13013, 2008.

Saarikoski, S., Frey, A., Mäkelä, T., and Hillamo, R.: Size distribution measurement of carbonaceous particulate matter using a 
low pressure impactor with quartz fiber substrates, Aerosol. Sci. Technol., 42, 603-612, 2008.

Salmon, L. G., Hildemann, L. M., Mazurek, M., Christoforou, C., Frei, N. A., Solomon, P. A., Schauer, J., Hughes, L., and Johnson, R.: Procedures Manual, Environ. Qual. Laboratory, Calif. Inst. of Technol., Pasadena, Calif., August 1998.

Schmid, H., Laskus, L., Abraham, H. J., Baltensperger, U., Lavanchy, V., Bizjak, M., Burba, P., Cachier, H., Crow, D., Chow, J., Gnauk, T., Even, A., ten Brink, H. M., Giesen, K.-P., Hitzenberger, R., Hueglin, C., Maenhaut, W., Pio, C., Carvalho, A., Putaud, J.-P., Toom-Sauntry, D., and Puxbaum, H.: Results of the carbon conference international aerosol carbon round robin test stage I, Atmos. Environ., 35, 2111-2121, 2001.

Schmid, O., Artaxo, P., Arnott, W. P., Chand, D., Gatti, L. V, Frank, G. P., Hoffer, A., Schnaiter, M., and Andreae, M. O.: Spectral light absorption by ambient aerosols influenced by biomass burning in the Amazon Basin. I: Comparison and field calibration of absorption measurement techniques, Atmos. Chem. Phys., 6, 3443-3462, 2006, http://www.atmos-chem-phys.net/6/3443/2006/.

Schnaiter, M., Horvath, H., Mohler, O., Naumann, K. H., Saathoff, H., and Schock, O. W.: UV-VIS-NIR spectral optical properties of soot and soot-containing aerosols, J. Aerosol Sci., 34, 14211444, 2003.

Sciare, J., Oikonomou, K., Favez, O., Liakakou, E., Markaki, Z., Cachier, H., and Mihalopoulos, N.: Long-term measurements of carbonaceous aerosols in the Eastern Mediterranean: evidence of long-range transport of biomass burning, Atmos. Chem. Phys., 8, 5551-5563, doi:10.5194/acp-8-5551-2008, 2008.

Solomon, P. A., Moyers, J. L., and Fletcher, R. A.: High-volume dichotomous virtual impactor for the fractionation and collection of particles according to aerodynamic size, Aerosol Sci. Technol., 2, 455-464, 1983.
Trebs, I., Metzger, S., Meixner, F. X., Helas, G., Hoffer, A., Rudich, Y., Falkovich, A., Moura, M. A. L., Da Silva, R. J., Artaxo, P.Slanina, J., and Andreae, M. O.: The $\mathrm{NH}_{4}^{+}-\mathrm{NO}_{3}^{-}-\mathrm{Cl}^{-}-\mathrm{SO}_{4}^{2-}$ $\mathrm{H}_{2} \mathrm{O}$ aerosol system and its gas phase precursors at a pasture site in the Amazon Basin: How relevant are mineral cations and soluble organic acids?, J. Geophys. Res., 110, D07303, doi:10.1029/2004JD005478, 2005.

Turpin, B. and Lim, H.: Species contributions to $\mathrm{PM}_{2.5}$ mass concentrations: revisiting common assumption for estimating organic mass, Aerosol. Sci. Technol., 35, 602-610, 2001.

Watson, J. G., Chow, J. C., and Chen, L.-W. A.: Summary of organic and elemental carbon/black carbon analysis methods and intercomparisons, Aerosol Air Qual. Res., 5(1), 65-102, 2005.

Watson, J. G., Chow, J. C., and Chen, L.-W. A.: Methods to assess carbonaceous aerosol sampling artifacts for IMPROVE and other long-term networks, J. Air Waste Manage., 59, 8, 898-911, 2009.

Weingartner, E., Saathoff, H., Schnaiter, M., Streit, N., Bitnar, B., and Baltensperger, U.: Absorption of light by soot particles: Determination of the absorption by means of aethalometers, J. Aerosol Sci., 34, 1445-1463, 2003.

Yokelson, R. J., Christian, T. J., Karl, T. G., and Guenther, A.: The tropical forest and fire emissions experiment: laboratory fire measurements and synthesis of campaign data, Atmos. Chem. Phys., 8, 3509-3527, doi:10.5194/acp-8-3509-2008, 2008.

Zhen, J., Xu, J., and Yang, H., Charring characteristics of atmospheric organic particulate matter in thermal analysis, Environ. Sci. Technol., 3, 6754-761, 2002. 